CAPÍTULO 6

\title{
TRABALHO E RENDA
}

\section{APRESENTAÇÃO}

A economia brasileira em 2015 passou por um momento delicado e, em termos agregados, os principais indicadores do mercado de trabalho brasileiro evoluíram de forma preocupante no passado recente. No resultado para o terceiro trimestre de 2015, o produto interno bruto (PIB) caiu 4,5\% em relação ao mesmo período de 2014, sendo esta a taxa mais negativa em toda a série histórica do Instituto Brasileiro de Geografia e Estatística (IBGE), iniciada em 1996. ${ }^{1}$ Foi a sexta retração seguida do PIB nesta base de comparação, tornando-se o período recessivo mais longo da história recente do país. Desde que a economia brasileira entrou em recessão, no segundo trimestre de 2014, a queda acumulada do PIB aproxima-se de $6 \%$, também um recorde dos últimos vinte anos. Já em relação à inflação, o índice de preços ao consumidor amplo (IPCA) encerrou outubro com uma taxa de variação, acumulada em doze meses, próxima a 10\%, mantendo tendência de aceleração e atingindo o pior resultado desde o final de 2000.

O mercado de trabalho vem sendo duramente afetado por esse quadro de desaquecimento econômico e inflação elevada, além do contexto político marcado por incertezas. O Cadastro Geral do Emprego e Desemprego (Caged) do Ministério do Trabalho (MTE) registrou a perda de quase 1,4 milhão de postos de trabalho entre janeiro e outubro de 2015. A taxa de desemprego medida pela Pesquisa Mensal do Emprego, do IBGE, atingiu 7,9\%, em outubro de 2015, com aumento de 3,2 pontos percentuais em relaçáo ao mesmo mês de 2014, e o desemprego medido pela Pesquisa Nacional por Amostra de Domicílios Contínua (Pnad Contínua), também do IBGE, chegou a 8,9\%, com alta de 2,1 pontos percentuais (p.p.) na mesma comparaçáo.

Este capítulo inicia-se com uma discussão dos possíveis fatores, com destaque para as decisóes tomadas no âmbito da chamada Nova Matriz Econômica, que levaram ao quadro atual de queda significativa do nível de atividade e inflação elevada. Nesse contexto, são apresentados os possíveis cenários para o mercado de trabalho brasileiro em um futuro próximo (subseção 2.1). Cenários marcados por iniciativas de política laboral que parecem colaborar relativamente pouco para a superação da crise.

1. Ver Carta de Conjuntura do Ipea n. 29, dez. 2015. Disponível em: <www.ipea.gov.br>. 
Em seguida, faz-se uma apresentação da conjuntura do mercado de trabalho brasileiro de 2015 com base na Pnad Contínua (subseção 2.2).

A seção 2 deste capítulo trata também de temas concernentes à legislação trabalhista. Um deles trata da Lei $\mathrm{n}^{\circ}$ 13.134, sancionada em junho de 2015, referente à Medida Provisória no 465 (MP no 465), a primeira medida provisória do ajuste fiscal sancionada pelo governo da presidente Dilma Rousseff (subseção 2.3). Basicamente, tal medida restringe o acesso a direitos trabalhistas associados ao seguro-desemprego, ao abono salarial e ao seguro-defeso. Outro tema legislativo tratado nessa seção aborda a Lei Complementar no 150 (LC no 150), sancionada em $1^{\circ}$ de junho de 2015 (subseçáo 2.4). Até essa data, o emprego doméstico apresentava uma singularidade em sua legislação na medida em que não era regido pela Consolidação das Leis do Trabalho (CLT), de 1943, mas por lei especial (Lei no 5.859/1972) e pela Constituição Federal de 1988, alterada pela Emenda Constitucional no 72 (EC no 72, de 2 de abril de 2013). Conhecida como a "PEC das domésticas", essa emenda suscitou amplo debate na sociedade, e as mudanças com relação aos direitos das empregadas domésticas foram bastante disseminadas na época. Porém, nem todas as mudanças propostas pela nova legislação tornaram-se efetivas na prática imediatamente após a aprovação da emenda. Com a LC no 150 , os direitos dos trabalhadores domésticos aproximam-se cada vez mais dos demais trabalhadores brasileiros.

Por fim, a seção 2 faz uma análise da Medida Provisória no 680/2015, com regras para o chamado Plano de Proteção do Emprego (PPE). ${ }^{2}$ Em linhas gerais, esse plano é uma tentativa de minimizar as consequências dessa dinâmica negativa, especificamente em termos de desemprego. Sua finalidade é permitir que as empresas reduzam o tempo de trabalho e o salário e, ao mesmo tempo, mantenham os atuais postos de trabalho.

Quanto às principais políticas do MTE, a seção 3 aponta as tendências de financiamento de políticas, além do desempenho recente dos programas de seguro-desemprego, de abono-salarial e de intermediação de mão de obra.

A última seção deste capítulo discute terceirização do trabalho no Brasil. Em particular, faz-se uma análise do projeto de Lei no 4.330/2004 que, entre as diversas propostas em tramitação no parlamento brasileiro, é a que se encontra mais à frente no processo legislativo. Como será visto, há dúvidas quanto ao projeto ser a melhor opção para definir uma regulação legislativa da terceirização. Provavelmente, mais avaliaçóes de impacto deste fenômeno deveriam ser realizadas, antes de qualquer decisão do parlamento sobre esse projeto de lei. 


\section{FATOS RELEVANTES}

\subsection{Contexto econômico e perspectivas para o mercado de trabalho}

Desde a metade de 2014, a economia brasileira se viu afetada por um clima bastante negativo, que resultou de uma série de fatores. Entre estes, é possível destacar as decisóes tomadas no âmbito da denominada Nova Matriz Econômica.

Entre os propósitos dessa matriz, destaca-se a promoção de

uma nova fase de desenvolvimento econômico e social, em que se combinam crescimento econômico com redução nas desigualdades sociais [...], especialmente por meio [...] da retomada do papel do Estado no estímulo ao desenvolvimento e no planejamento de longo prazo (Barbosa e Souza, 2010).

Anunciada publicamente pelo governo ainda no final de 2010 (Barbosa e Souza, 2010; Barbosa, 2011; Mantega, 2012), essa matriz foi constituída por iniciativas $\mathrm{como}^{3}:$ i) no que se refere à política monetária: uma redução acentuada das principais taxas de juros da economia, bem como uma ampla expansão do crédito, ${ }^{4}$ para fomentar o consumo das famílias e os investimentos das empresas; ii) política cambial: uma desvalorização da taxa de câmbio, levando em conta os salários ponderados pela produtividade do trabalho, com o objetivo de estimular as exportaçóes das empresas industriais; iii) política tributária: uma diminuição de tributos, como dos voltados para o consumo de bens (autoveículos, eletrodomésticos etc.), bem como daqueles focados em salários (para financiar a previdência social), para promover o consumo das famílias e os investimentos das empresas; iv) política fiscal: um aumento acentuado do gasto estatal, especialmente em infraestrutura (energia, transporte, comunicação, habitação, saneamento etc.), ${ }^{5}$ com o intuito de estimular os investimentos das empresas (inclusive das estatais); v) política de produção/de comércio: várias iniciativas, referentes a compras públicas, a importações/exportaçóes etc., para apoiar investimentos no desenvolvimento das cadeias de insumos envolvendo empresas industriais (em setores como os de energia e de defesa).

Apesar dos propósitos definidos na concepção dessa matriz econômica, os resultados da sua aplicação mostraram-se muito negativos. Há um debate intenso, entre economistas de vários matizes e filiaçōes, sobre os motivos desse descompasso

3. Saliente-se que o contexto internacional vigente na origem desta matriz caracterizou-se por um ritmo lento da atividade econômica nos países desenvolvidos (com baixa inflação e alto desemprego), bem como por políticas para fomentar esta atividade (em especial, políticas monetárias e fiscais relaxadas e expansivas). Acerca disso, ver Barbosa e Souza (2010); Barbosa (2011).

4. Essa expansão do crédito, em benefício das famílias e das empresas, foi realizada principalmente por bancos estatais, como o Banco Nacional de Desenvolvimento Econômico e Social (BNDES), a Caixa Econômica Federal (CEF) e o Banco do Brasil (BB). Sobre isso, ver Almeida (2014); Barros (2014a); Pessoa (2015).

5. Outros elementos desse gasto estatal também vinham aumentando, como o desembolso na área social (destacando-se as transferências de previdência social e os serviços de educação). 
entre os propósitos e os resultados. ${ }^{6}$ De qualquer forma, o fato é que esses resultados negativos mostraram-se por inteiro na economia, particularmente após a metade de 2014. Só para citar alguns deles: i) problemas com a conta externa (principalmente devido a desequilíbrios no comércio, com importaçóes maiores do que exportaçóes). ii) preocupaçóes com a conta fiscal (com gastos estatais maiores do que as receitas fiscais, entre outras coisas); 7 iii) dificuldades com o encolhimento dos investimentos (especialmente em relação às empresas estatais, como a Petrobras, a Eletrobras etc.) ${ }^{8}$ iv) preocupaçôes com a aceleração e a disseminação da inflação (inflação de todos os tipos, incluindo aquela sob o controle direto do governo); v) problemas com a contração do consumo das famílias, pela primeira vez em anos (consumo de bens e também de serviços).

Provavelmente, o resultado mais importante de todos esses problemas tem sido a contração econômica no ano em curso. O PIB brasileiro deve ter caído 3,5\% no ano de 2015 (Brasil, 2015), na direção oposta da maioria dos países periféricos incluindo vários da América Latina (FMI, 2015).

Seguindo nessa direção, o mercado de trabalho também tem se contraído. Em termos agregados, os principais indicadores do mercado de trabalho brasileiro apontam um quadro preocupante. Tanto a taxa de desemprego como a taxa de informalidade registram crescimentos expressivos no primeiro semestre de 2015. Em particular, a taxa de desemprego foi pressionada não só por um aumento na participação como também por uma queda no nível de ocupação. Ou seja, do ponto de vista quantitativo, a geração de postos de trabalho diminuiu, bem como a qualidade dos postos tem piorado nos últimos meses, ao menos nas dimensóes captadas pela informalidade.

Apesar de a elevação na taxa de desemprego e na informalidade, juntamente com a queda na taxa de ocupação e nos rendimentos médios reais, indicar um quadro delicado por si só, talvez ainda mais preocupante seja a ausência de indícios de reversão nesse contexto. Pelo contrário, a contratação por salários cada vez menores constitui um fator que tende a contribuir para o agravamento no desempenho desse mercado em um futuro próximo.

6. Diferentes perspectivas nesse debate são encontradas em Almeida (2013, 2014); Almeida, Lisboa e Pessoa (2015); Barros (2014a, 2014b); Belluzzo (2014, 2015); Canuto e Schellekens (2014); Pessoa (2014, 2015); Romero (2014, 2013); Tavares, Belluzzo, Bielschowsky (2014b); Tavares, Belluzzo, Bresser-Pereira (2014a); Ubide (2015).

7. Aparentemente, esses problemas com a conta fiscal resultaram em adiamento de pagamentos devidos pelo Estado, bem como em problemas na contabilidade do Estado. A propósito, a credibilidade das estatísticas relacionadas a essa contabilidade tem sido questionada por instituições especializadas. Sobre tudo isso, ver: TCU (2015).

8. Nos últimos anos, as empresas estatais sofreram com: i) o processo de definição de preços por parte do governo (fixação de preços de petróleo/gás no setor da energia, por exemplo); ii) o processo de regulaçã̃o do governo sobre a produção/comercialização de bens/serviços (novas regras para a produção/distribuição de eletricidade, por exemplo); iii) diversos outros problemas, que vêm sendo tratados no âmbito da justiça criminal federal. Sobre isso, ver (Barros, 2014a); (Pessoa, 2015); (Ubide, 2015). 
A análise desagregada por diversos segmentos da população também aponta um aspecto preocupante para a reversão desse quadro. A deterioração dos indicadores afeta, sobretudo, os homens e os mais escolarizados. Ambos os segmentos experimentaram quedas relativamente expressivas na taxa de ocupaçáo com consequente aumento de desemprego aliado a aumentos relativamente expressivos também na taxa de informalidade. Dado que esse grupo tende a ter papel relevante na geração da renda familiar, pode haver um reflexo da deterioração no mercado de trabalho para o bem-estar das famílias.

Por outro lado, os trabalhadores acima de 60 anos de idade registraram aumento na taxa de ocupação acompanhado de diminuição na taxa de informalidade. Esse grupo só não registrou uma queda na taxa de desemprego devido a um expressivo aumento na taxa de participação, que também foi observado para as mulheres.

Grosso modo, a reação do governo a esse quadro de contração (ou mesmo deterioração), em termos de políticas laborais, foi marcada essencialmente pela reformulação dos programas do seguro-desemprego e do abono salarial, com a edição da Medida Provisória no 665/2014 (convertida depois na Lei no 13.134/2015).

Mas, com isso, o governo estava na verdade tentando mitigar alguns dos problemas da política fiscal. Ou seja, o objetivo do governo não era propriamente resolver os problemas dessas políticas laborais. O objetivo era atenuar os problemas fiscais, que estavam afetando toda a economia, como descrito anteriormente.

Em certa medida, isso explica a natureza das medidas proclamadas pela Lei $n^{\circ} 13.134 / 2015$, destinadas a restringir o acesso dos trabalhadores a esses programas, bem como a proteçấo que deles obtinham. O propósito do governo era limitar o gasto de recursos que se mostravam bastante escassos, dado o contexto econômico.

Outra parte da reação do governo foi o Programa de Proteção ao Emprego (PPE), por meio do qual esperava amenizar alguns dos aspectos mais negativos desse contexto, como a elevação das taxas de desemprego. Com esse programa, esperava-se que as empresas, em troca de um incentivo fiscal, não desligassem seus trabalhadores, mas sim reduzissem suas jornadas e suas remuneraçóes. Mas, diante da grande dimensão que vem assumindo o fenômeno do desemprego, bem como diante do pequeno volume de incentivo fiscal disponível, é de se questionar o real impacto do PPE no mercado de trabalho.

Enfim, com alguma probabilidade, a resolução dos problemas que vêm afligindo esse mercado no Brasil não virá por meio de iniciativas do governo no âmbito da política laboral. Mas virá, provavelmente, mediante iniciativas na esfera da política econômica, capazes de ampliar o investimento das empresas e, consequentemente, o crescimento do produto. Ganhos reais em termos de ocupação, formalização e remuneração dos trabalhadores devem originar-se daí - 
por mais que, nesse momento, dadas as dinâmicas negativas da economia, esses ganhos pareçam muito, muito distantes.

\subsection{Conjuntura do mercado de trabalho $2015^{9}$}

Esta análise tem por objetivo avaliar o comportamento do mercado de trabalho brasileiro dos três primeiros trimestres de 2015, com base nos dados da Pnad Contínua/IBGE, procurando referenciá-lo no contexto de seu desempenho nos últimos anos, principalmente os três primeiros trimestres de 2014, de modo a minimizar interferências de ordem sazonal.

A análise a seguir mostra a trajetória da taxa de desemprego para os anos de 2012 a 2015 . Entre janeiro e setembro de 2015, a taxa de desemprego apresentou um valor médio de $8,4 \%$, ficando 1,5 p.p. acima do verificado para o mesmo período de 2014, quando registrou $6,9 \%$. Vale destacar o considerável aumento entre o quarto trimestre de 2014, quando a taxa foi de $6,5 \%$, e o terceiro trimestre de 2015, quando a taxa de desemprego atingiu $8,9 \%$. No gráfico 1 , é possível notar que a magnitude deste aumento nos três primeiros trimestres de 2015 destoa dos registrados ao longo dos mesmos períodos dos outros anos recentes.

GRÁFICO 1

Taxa de desemprego

(Em \%)

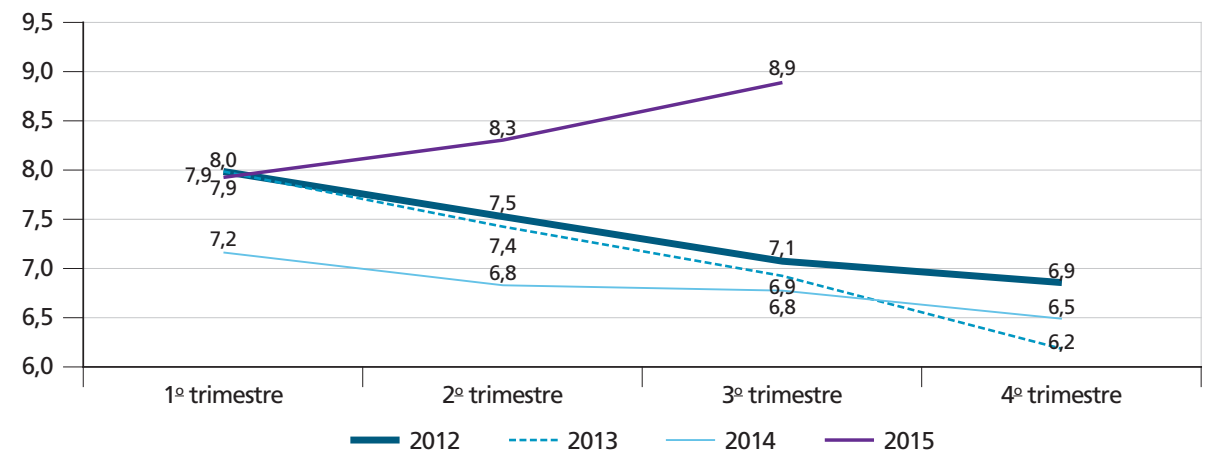

Fonte: Pnad Contínua/IBGE e Boletim de Mercado de Trabalho do Ipea, n. 58 (2015).

O gráfico 2 ilustra a evolução da taxa de participação (ou taxa de atividade) ao longo dos anos de 2012 a $2015 .{ }^{10}$ A média da taxa de atividade para os três primeiros trimestres de 2015 ficou estável em relação ao mesmo período de 2014 (em torno de $61,1 \%$ ). Nota-se, porém, que essa taxa cresceu de $60,9 \%$, no quarto trimestre de 2014, para 61,4\%, no terceiro trimestre de 2015. Esse crescimento

9. Essa seção aproveita o conteúdo do Boletim de Mercado de Trabalho do Ipea, n. 58. 
contrasta com uma estabilidade registrada para os primeiros semestres de $2014 \mathrm{e}$ de 2013. Ou seja, houve uma pressão no desemprego vindo pelo lado da oferta de trabalho no primeiro semestre de 2015.

GRÁFICO 2

Taxa de participação

(Em \%)

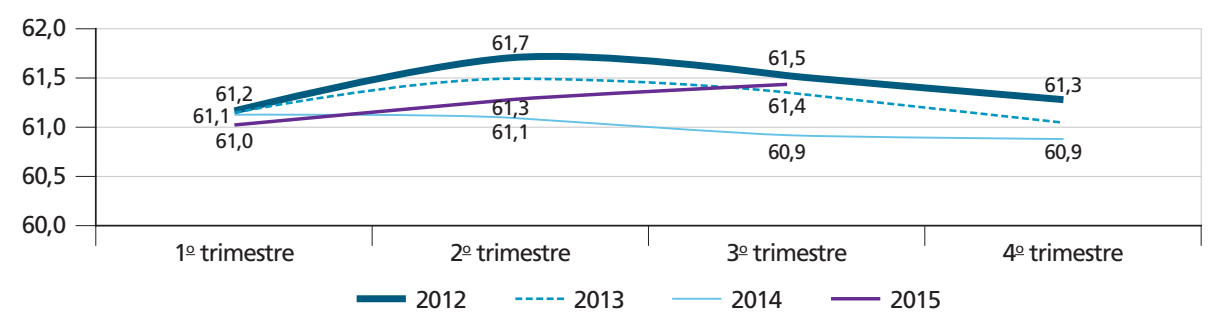

Fonte: Pnad Contínua/IBGE e Boletim de Mercado de Trabalho do Ipea, n. 58 (2015).

Ao analisar a ocupação nos últimos anos, verifica-se que nos três primeiros trimestres de 2015 a média da populaçáo ocupada foi de aproximadamente 92,1 milhóes. Esse valor agregado apresentou uma variação de 0,3\% em comparação com o mesmo período do ano anterior, o que representa um crescimento de aproximadamente 251 mil postos de trabalho. Por sua vez, a taxa de ocupação, medida pela proporção de ocupados em relação à população em idade de trabalhar (às vezes denotada por PIA), registra uma queda de $1,2 \%$ nesse mesmo período, passando de $56,8 \%$, nos três primeiros trimestres de 2014 , para um valor médio de 56,1\%, no mesmo período de 2015. A evolução trimestral desse indicador entre os anos de 2012 e 2015 é apresentada no gráfico 3. Nele, é possível notar que o nível de ocupação caiu nos três primeiros trimestres de 2015, passando de aproximadamente 92,9 milhóes de ocupados, no quarto trimestre de 2014, para 92,1 milhóes, no terceiro trimestre de 2015. Já em 2014 e 2013, houve um crescimento para o mesmo período do ano.

Juntando as peças apresentadas até aqui, tivemos um primeiro semestre desse ano com aumento da força de trabalho, mas com diminuição de postos de trabalho. Essa combinação explica o aumento expressivo da taxa de desemprego nesses primeiros nove meses de 2015.

Analisando a evolução da população ocupada por posição na ocupação nos três primeiros trimestres de 2015, em relação ao mesmo período de 2014, o destaque positivo fica por conta dos empregadores e dos ocupados por conta própria que registraram crescimento médio de $8,2 \%$ e $4,1 \%$, respectivamente. Já os trabalhadores sem carteira e com carteira assinada apresentaram decréscimo de $1,2 \%$ e $2,1 \%$, respectivamente. ${ }^{11}$ 
GRÁFICO 3

Número de ocupados

(Em milhares)

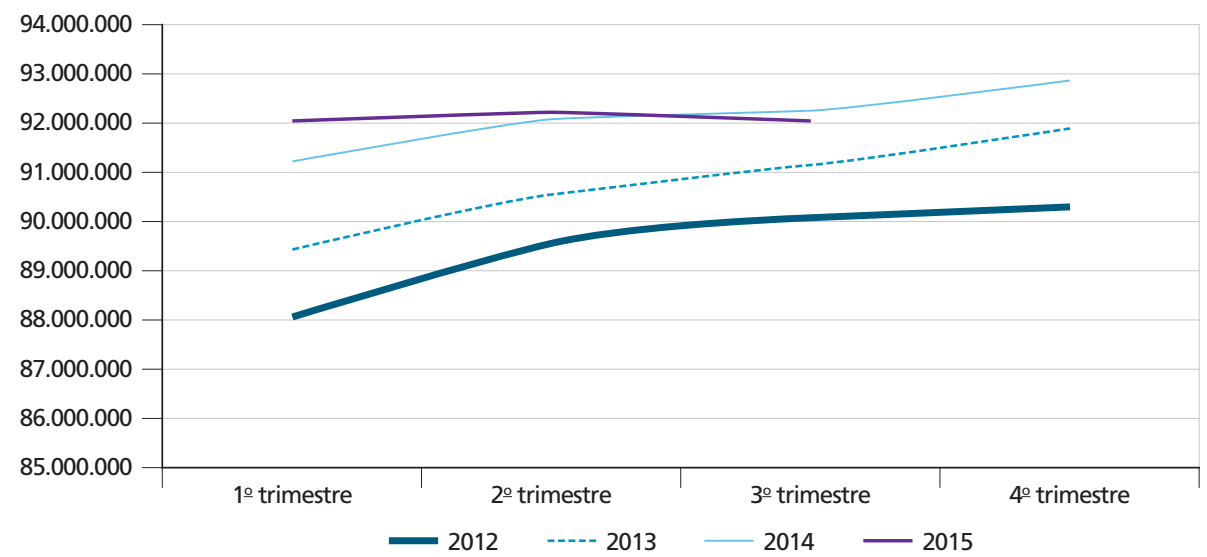

Fonte: Pnad Contínua/IBGE e Boletim de Mercado de Trabalho do Ipea, n. 58 (2015).

GRÁFICO 4

Evolução do grau de informalidade

(Em \%)

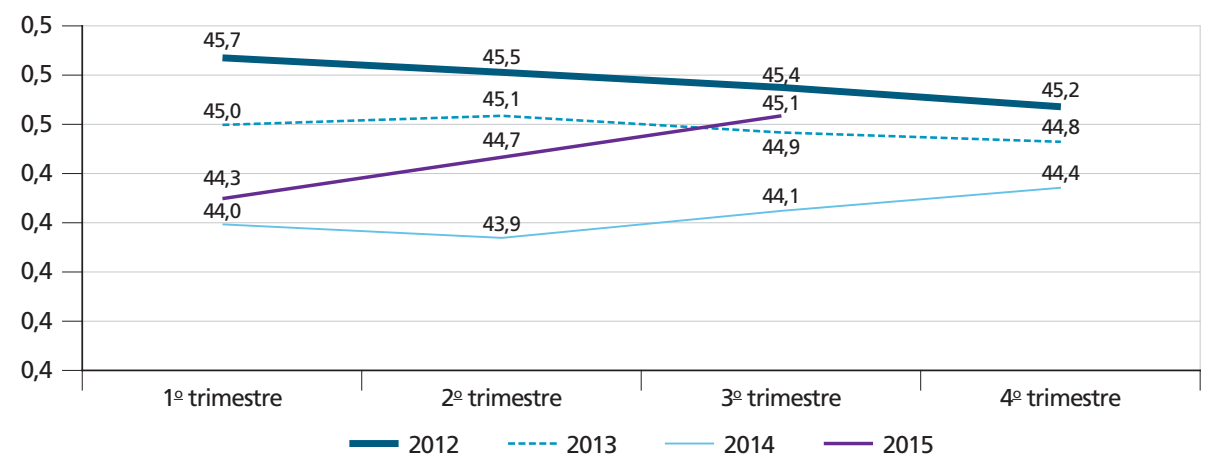

Fonte: Pnad Contínua/IBGE e Boletim de Mercado de Trabalho do Ipea, n. 58 (2015).

O contraste entre os resultados dos grupos dos trabalhadores protegidos (com carteira e militares ou funcionários públicos) dos empregadores em relação ao grupo dos empregados sem carteira junto com os trabalhadores conta própria e não remunerados moldam a evolução do grau de informalidade. ${ }^{12} \mathrm{O}$ gráfico 4 permite dizer que o nível de informalidade médio da população ocupada, nos três primeiros trimestres de 2015 , ficou em $44,7 \%$, o que representa um crescimento 
de 0,7 p.p. em relação a 2014. Vale destacar que a taxa em 2015 encontra-se em um patamar superior a 2014 e vem apresentando crescimento desde o $2^{\circ}$ semestre de 2014 quando atingiu seu menor valor (43,9\%).

GRÁFICO 5

Rendimento médio real habitual no trabalho principal

(Em R\$ de maio de 2015)

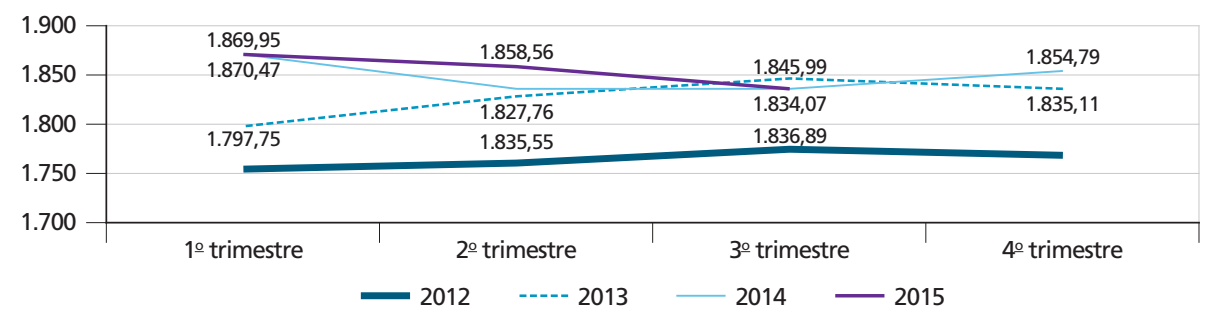

Fonte: Pnad Contínua/IBGE e Boletim de Mercado de Trabalho do Ipea, n. 35 (2015).

Obs.: Corrigido pelo IPCA15.

GRÁFICO 6

Massa salarial

(Base 20 trimestre de $2015=100$ )

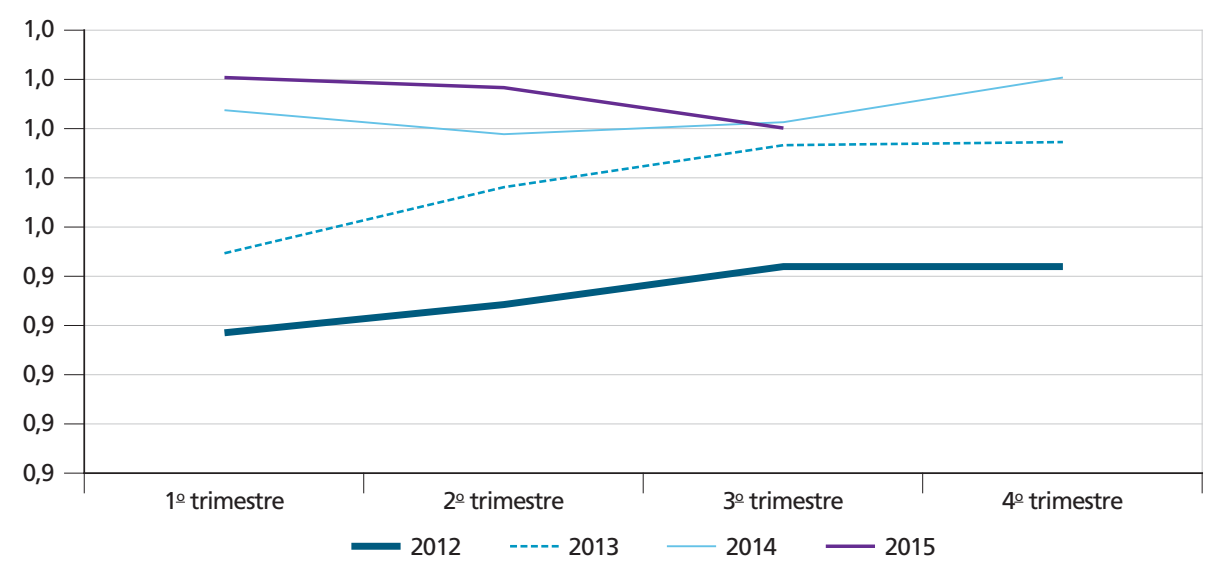

Fonte: Pnad Contínua /IBGE e Boletim de Mercado de Trabalho do Ipea, edição n. 58 (2015).

Obs.: Corrigido pelo IPCA15.

O rendimento médio real habitualmente recebido registrou um ganho médio de $0,4 \%$, nos três primeiros trimestres de 2015, em comparação ao mesmo período de 2014 , ficando em torno de $\mathrm{R} \$ 1.854,19$ e registrou, no terceiro trimestre, o valor de $1.834,07$, um pouco abaixo do primeiro trimestre de 2015 , que foi de $1.869,95$ (recuo de $0,7 \%$ ). No gráfico 5 , é possível notar o que rendimento real fecha o terceiro trimestre de 2015 em um valor muito próximo ao registrado no quarto trimestre de 2014 ( $\mathrm{R} \$ 1.836,89)$. 
No gráfico 6, observa-se a evolução da massa salarial de 2012 a $2015 .{ }^{13}$ Nele, pode-se notar que o indicador apresenta uma tendência de leve queda nos três primeiros trimestres de 2015. Na comparação entre a média do terceiro trimestre de 2015 com relação ao mesmo período de 2014, nota-se uma estabilidade desse indicador.

Em termos agregados, os principais indicadores do mercado de trabalho brasileiro apontam um quadro preocupante. Tanto a taxa de desemprego como a taxa de informalidade registram crescimentos expressivos no primeiro semestre de 2015. Em particular, a taxa de desemprego foi pressionada não só por um aumento na oferta de trabalho como também por uma queda no nível de ocupação. Ou seja, a geração de postos de trabalho diminuiu, bem como a qualidade dos postos tem piorado nos últimos meses, ao menos nas dimensóes captadas pela informalidade.

\subsection{Seguro-desemprego, seguro-defeso e abono salarial: as novas regras da Lei $\mathrm{n}^{\circ} \mathbf{1 3 . 1 3 4 / 2 0 1 5}$}

No final de 2014, o governo decidiu reformular os programas do seguro-desemprego

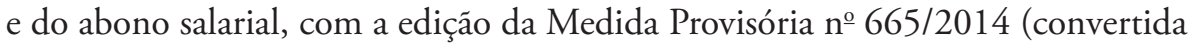
posteriormente na Lei oํ 13.134/2015). Entre outras coisas, com isso, o governo estava tentando mitigar problemas da política fiscal. Ou seja, em alguma medida, o objetivo do governo não era tanto resolver os problemas de eficácia e eficiência do seguro-desemprego e do abono salarial, ${ }^{14}$ mas sim atenuar os problemas fiscais, que estavam afetando toda a economia.

Isso ajuda a explicar a natureza das medidas proclamadas pela Lei no 13.134/2015, destinadas a restringir o acesso dos trabalhadores a esses programas, bem como a proteção que deles obtinham. Note-se que, historicamente, o financiamento do seguro-desemprego e do abono salarial foi realizado pelo Fundo de Amparo ao Trabalhador (FAT) - que, nos últimos anos, já estava sofrendo de escassez de recursos. ${ }^{15}$

\subsubsection{Alguns aspectos da Lei ㄲo 13.134/2015}

Com a intenção de reformular o seguro-desemprego e o abono salarial, a Lei no $13.134 / 2015$ estabeleceu novas regras, a serem observadas pelos trabalhadores que podem se beneficiar desses programas.

Em primeiro lugar, no que diz respeito ao seguro-desemprego (devido aos desempregados involuntários, antes formalmente empregados), pode-se destacar as seguintes regras a seguir. ${ }^{16}$

13. A massa salarial representa a soma de todos os salários pagos aos trabalhadores durante o trimestre.

14. Há diversos problemas que afetam a eficácia e a eficiência do seguro desemprego e do abono salarial. Sobre isso, ver Campos e Chaves, 2014; CUT/Dieese, 2011; Marinho, Balestro e Walter, 2010.

15. Sobre isso, verificar Amorim et al, 2012.; Cardoso Jr. e Gonzalez, 2007.

16. Regras que alteram a Lei no $7.998 / 1990$, que regula os principais aspectos do seguro-desemprego no Brasil. 
1) Regras que redefinem o tempo de trabalho anterior exigido para acessar o programa:

a) antes da Lei no $13.134 / 2015$, os trabalhadores deviam ter seis meses de emprego formal remunerado para se beneficiar do seguro;

b) depois da lei, eles devem ter: i) 12 meses de emprego formal remunerado nos últimos 18 meses, se estáo demandando o seguro pela primeira vez; ii) nove nos últimos 12 meses, se estão demandando pela segunda vez; iii) seis meses, se estáo demandando pela terceira vez (ou mais).

2) Regras que redefinem o número de parcelas mensais pagas aos trabalhadores elegíveis:

a) antes da lei, deviam ser pagas aos trabalhadores: i) três parcelas, se tivessem trabalhado entre seis e 11 meses nos últimos 36 meses; ii) quatro parcelas, se tivessem trabalhado entre 12 e 23 meses; iii) cinco parcelas, se tivessem trabalhado mais que 24 meses.

b) Depois da lei, devem ser pagas aos trabalhadores:

b.1) Na primeira vez que estão demandando o seguro: $i$ ) quatro parcelas, se têm entre 12 e 23 meses de trabalho nos últimos 36 meses; ii) cinco parcelas, se têm mais que 24 meses;

b.2) Na segunda vez que estão demandando o seguro: $i$ ) três parcelas, se têm entre nove e 11 meses de trabalho nos últimos 36 meses; ii) quatro parcelas, se têm entre 12 e 23 meses; iii) cinco parcelas, se têm mais que 24 meses.

b.3) Na terceira vez (ou mais) que estáo demandando o seguro: i) três parcelas, se têm entre seis e 11 meses de trabalho nos últimos 36 meses; ii) quatro parcelas, se têm entre 12 e 23 meses; iii) cinco parcelas, se têm mais que 24 meses.

Em suma, de acordo com a Lei no 13.134/2015, para acessar o seguro-desemprego, os trabalhadores têm de seguir regras mais rigorosas. Em particular, em termos do montante de tempo de trabalho anterior ao requerimento. O montante mínimo, no primeiro pedido, é agora de 12 meses (duas vezes o anterior). E só na terceira requisiçáo do seguro é que o montante permanece o mesmo (seis meses).

Em segundo lugar, a respeito do seguro-defeso, modalidade de seguro-desemprego focada em pescadores artesanais (incapazes de subsistirem com base em seu trabalho, durante o período do ano em que a pesca não está autorizada), a Lei no $13.134 / 2015$ estabeleceu as seguintes regras: ${ }^{17}$

17. Regras que alteram a Lei o $10.779 / 2003$, que regula os principais aspectos dessa modalidade de seguro desemprego (com foco em pescadores artesanais) no Brasil. 
1) Regras sobre quem são os trabalhadores elegíveis para o programa:

a) antes da Lei no $13.134 / 2015$, não havia restriçóes para beneficiar trabalhadores envolvidos em atividades de apoio à pesca (atividades como reparação de navios, manutenção de equipamentos de pesca, limpeza de peixes etc.);

b) depois da lei, os trabalhadores beneficiados são apenas aqueles direta e imediatamente envolvidos em atividades de pesca (excluindo aqueles em atividades de apoio).

2) Regras sobre o número de parcelas mensais pagas a trabalhadores elegíveis:

a) antes da lei, esse número era definido pelo período de restrição da pesca (o período de defeso, em que as espécies não podem ser pescadas);

b) depois da lei, esse número é restrito para o mesmo número máximo de parcelas pagas aos beneficiários do seguro-desemprego (cinco), independentemente do período de restrição da pesca.

3) Regras sobre a acumulação de benefícios pelos trabalhadores elegíveis:

a) antes da lei, não havia restrições para a acumulação de benefícios relacionados a diferentes espécies de peixes (diferentes defesos);

b) depois da lei, os trabalhadores podem obter somente um benefício de seguro-defeso, referente a apenas uma espécie de peixe;

c) antes da lei, não havia restrição à acumulaçáo de benefícios do seguro-defeso e dos programas de transferência condicional de renda (como o bolsa família);

d) depois da lei, quando os trabalhadores estão recebendo o seguro-defeso, eles não podem receber a transferência de renda ao mesmo tempo (esta última deve ser temporariamente suspensa).

4) Regras sobre a gestão do programa:

a) Antes da lei, a gestão do dia a dia do seguro-defeso era uma incumbência do Ministério do Trabalho (apesar da influência das decisóes do Ministério da Pesca, quanto à identificação dos trabalhadores com direito ao seguro).

b) Depois da lei, essa gestão foi transferida para o Ministério da Previdência Social ${ }^{18}$ (que, alegadamente, tem mais capacidades e recursos para implantar e monitorar o programa). 
Em suma, no que diz respeito a esta modalidade de seguro-desemprego, denominada seguro-defeso, a Lei no ${ }^{-13.134 / 2015}$ impôs regras mais rigorosas para os trabalhadores, restringindo seu acesso aos benefícios. Em especial, alguns dos trabalhadores, como os envolvidos em atividades de apoio à pesca (de preparação dos instrumentos de trabalho, de comercializaçáo dos produtos da pesca etc.), foram deixados fora do programa. E mesmo aqueles que permaneceram no programa foram afetados por restriçōes sobre o número de benefícios (e o número de parcelas).

Em terceiro lugar, no que diz respeito ao abono salarial (devido a trabalhadores de baixa renda, com emprego formal remunerado por pelo menos trinta dias nos últimos doze meses, bem como cadastrados no PIS/Pasep há pelo menos cinco anos), ${ }^{19}$ a Lei $\mathrm{n}^{\mathrm{o}}$ 13.134/2015 definiu as seguintes regras, ${ }^{20}$ envolvendo o montante dos valores pagos aos trabalhadores elegíveis: i) antes da Lei no 13.134/2015, aos trabalhadores devia ser pago o valor exato de um salário-mínimo; ii) depois da lei, o valor a ser pago tem valor variável, proporcional ao número de meses trabalhados nos últimos doze meses - atingindo o máximo de um salário-mínimo.

Enfim, a respeito do abono salarial, a Lei no $13.134 / 2015$ não alterou as regras de acesso ao programa. No entanto, as regras que definem os valores a serem pagos aos trabalhadores foram modificadas, frequentemente reduzindo tais valores (tendo em conta que, no mercado de trabalho brasileiro, é bastante comum os trabalhadores não completarem um ano de emprego formal remunerado).

Um resumo das regras estabelecidas pela Lei no 13.134/2015 (com outras modificaçóes, além das anteriormente descritas) pode ser encontrado mais à frente, nos quadros do anexo deste texto.

\subsubsection{0 preço pago pela política social}

Em meio a numerosos e graves problemas, herdados da "Nova Matriz Econômica", a economia brasileira passou a desacelerar e mesmo a se contrair - algo que é particularmente evidente no ano de 2015, quando se espera a contração de algo como $3,5 \%$ no PIB. ${ }^{21}$

Como parte disso, o mercado de trabalho também desacelerou e passou a se contrair, como é possível perceber na dinâmica da ocupação, do desemprego e do rendimento do trabalho - todas as variáveis com uma dinâmica bastante negativa no ano corrente.

Nesse contexto, o governo decidiu reformar dois dos principais programas entre as políticas laborais brasileiras: o seguro-desemprego e o abono salarial.

19. Sobre o PIS/Pasep, ver Amorim et al., 2012.

20. Regras que alteram a Lei no 7.998/1990, que regula os principais aspectos do abono salarial no Brasil.

21. Sobre isso, verificar BCB (2015). 
Ao que parece, a razão dessa reforma não foi qualquer ineficácia ou ineficiência atribuída a esses programas, mas apenas o seu dispêndio fiscal - é por conta disso que a Lei no 13.134/2015 impôs as regras anteriormente examinadas.

Aparentemente, o principal objetivo desta lei foi restringir o acesso dos trabalhadores ao seguro-desemprego e ao abono salarial, bem como reduzir o montante de dispêndios com esses programas. Em outras palavras, o objetivo principal foi reduzir os gastos estatais, relacionados com este tipo de proteção dos trabalhadores.

De qualquer forma, essa é provavelmente uma das principais contradiçóes da Lei no 13.134/2015: no exato momento em que os trabalhadores mais demandam proteçáo contra o aumento do desemprego e contra a queda do rendimento, o governo decidiu dificultar o acesso ao seguro-desemprego e ao abono salarial, os principais programas em meio às políticas laborais brasileiras.

Com certeza, essa decisão não foi gratuita ou desarrazoada. Diante dos acontecimentos na economia, já descritos, o governo adotou uma atitude fiscal restritiva - mesmo na área social. Parece que, hoje, a política social brasileira está pagando um preço (especialmente pesado) pelos problemas gerados pela política econômica dos últimos anos.

\subsection{Arcabouço institucional do emprego doméstico no Brasil e a Lei Complementar no 150/2015}

Ainda que tenha havido uma série de transformaçóes em seu mercado e na sua configuração ao longo dos últimos anos, o serviço doméstico remunerado continua sendo uma das principais ocupaçóes das mulheres brasileiras.

É caracterizado por uma ocupação de baixa remuneração e formalização e que absorve mulheres de baixa escolaridade e com pouca experiência profissional. A taxa de informalidade é maior entre as empregadas domésticas que são casadas e com filhos (Perry et al., 2007). Há ainda uma imobilidade ocupacional do emprego doméstico. Assim como ter como primeiro emprego o trabalho doméstico aumenta a probabilidade de as trabalhadoras permanecerem nesta mesma ocupação em comparação com quem não começou como doméstica (Saito e Souza, 2008).

Diante de tais características e da representação sociocultural e econômica do emprego doméstico no Brasil, a sanção da Lei Complementar no 150/2015 torna-se um marco histórico no que diz respeito a políticas públicas.

A Consolidação das Leis do Trabalho (CLT), de 1943, não incluiu o emprego doméstico na regulamentação dos direitos trabalhistas. ${ }^{22}$ Tal ocupação só foi o objeto

22. 0 Decreto-Lei ํㅜ 3.078, de 1941, foi o primeiro instrumento legal do trabalho doméstico no Brasil. Tal decreto dispôs sobre a locação dos empregados em serviço doméstico, determinando o uso da carteira profissional e aviso prévio de oito dias para vínculos com duração superior a seis meses, além de definir deveres do empregador e do empregado. No entanto, a sua efetiva vigência dependia de regulamentação. Tal fato jamais ocorreu, o que fez com que a categoria ficasse sem um respaldo jurídico de fato (Pinheiro, Gonzalez e Fontoura, 2012 e Fraga, 2010). 
de regulamentação em 11 de dezembro de 1972 pela Lei ํㅗ 5.859, que tornou obrigatória a assinatura da carteira de trabalho, o direito a férias anuais remuneradas de vinte dias úteis e o acesso obrigatório a benefícios e serviços da previdência social.

Mudanças significativas quanto aos direitos das trabalhadoras domésticas foram introduzidas na Constituição Federal de 1988. Além dos elencados na legislação de 1972, foram assegurados ao emprego doméstico os seguintes direitos no Parágrafo Único do Artigo 7ํㅡㅇ do texto constitucional: $i$ ) salário-mínimo; ii) irredutibilidade salarial; iii) décimo terceiro salário; iv) repouso semanal remunerado; v) férias anuais remuneradas com, pelo menos, um terço a mais que o salário normal; vi) licença maternidade de 120 dias; vii) licença paternidade; viii) aviso prévio proporcional ao tempo de serviço; e, ix) aposentadoria. A partir da Constituição de 1988, foi facultado o acesso do empregado doméstico ao FGTS e ao benefício do seguro-desemprego (Lei no 10.208, de 23/3/2001).

Entre outras alteraçóes, a Lei no 11.324/2006 alterou a legislaçáo do Imposto de Renda das Pessoas Físicas (IRPF) e introduziu a possibilidade de deduzir, do imposto devido, a contribuição paga à Previdência Social pelo empregador doméstico incidente sobre o valor da remuneração do empregado. O objetivo dessa medida era elevar o número de registros em carteira dos empregados domésticos, por meio de uma redução dos custos previdenciários incidentes para o empregador, via dedução no IR. ${ }^{23}$ Com o objetivo de se adequar à Convenção no 182 da Organização Internacional do Trabalho (OIT), que tratou da eliminação do trabalho infantil, o Decreto $\mathrm{n}^{\circ} \mathbf{6 . 4 8 1}$, de 2008, proibiu o trabalho doméstico para menores de dezoito anos.

A Emenda Constitucional no 72 (EC no $²$ ) foi aprovada pelo Congresso Nacional brasileiro em 2 de abril de 2013. Essa emenda, que ampliou os direitos trabalhistas das empregadas domésticas, resulta da Proposta de Emenda Constitucional no 66, de dezembro de 2012, PEC no 66/2012, que ficou amplamente conhecida como a "PEC das domésticas". A "PEC das Domésticas" suscitou amplo debate na sociedade e as mudanças com relação aos direitos das empregadas domésticas foram bastante disseminadas na época. A redação do Parágrafo Único do Artigo 7o da Constituição de 1988, que reforçava a excepcionalidade do emprego doméstico, foi alterada pela emenda de 2013 para incluir direitos como a jornada de trabalho definida (em oito horas diárias e 44 horas semanais) e pagamento de horas extras, que passaram a valer com a publicação da emenda. Porém, nem todas as mudanças propostas pela nova legislação tornaram-se efetivas na prática imediatamente após

23. Com essa lei, as férias passaram a ser de 30 dias corridos, em vez de vinte dias úteis, ficou vedado ao empregador doméstico efetuar descontos no salário do empregado por fornecimento de alimentação, vestuário, higiene e moradia, além de ficar prevista estabilidade no emprego até o quinto mês após o parto. Theodoro e Scorzafave (2011) chamam a atenção que este último aspecto poderia diminuir o impacto positivo da lei sobre o nível de formalização, contrabalanceando o efeito da redução dos encargos trabalhistas. 
a aprovação da EC no $72 .{ }^{24}$ Sete dos novos direitos contidos na emenda passaram a depender de regulamentação específica. Eram eles: fundo de garantia por tempo de serviço (FGTS), recebimento de multa em caso de demissão sem justa causa, seguro-desemprego, remuneração superior por trabalho noturno, salário-família, auxílio-creche e pré-escola e seguro contra acidentes de trabalho. ${ }^{25}$

Após dois anos da promulgação da EC no 72, em 1o de junho de 2015, a presidente Dilma Rousseff sancionou a Lei Complementar no 150 (LC no 150/2015), que regulamenta a "PEC das Domésticas", regulamentando assim os sete direitos já mencionados. ${ }^{26} \mathrm{~A}$ lei sancionada teve dois vetos, mas que não alteravam a essência do que foi aprovado pelo Congresso. ${ }^{27}$ Com a lei, foi instituído o Simples Doméstico, sistema que possibilita o recolhimento unificado dos tributos e do FGTS para os empregadores domésticos. ${ }^{28}$

Ainda que o objetivo da lei tenha sido aproximar os direitos das trabalhadoras domésticas aos dos demais trabalhadores urbanos e rurais no Brasil, não se sabe quais serão os reais efeitos dessa nova legislação sobre os indicadores agregados do mercado de trabalho doméstico e sobre a elevaçáo do bem-estar dessas trabalhadoras. Como esta lei é bastante recente, uma análise precisa de tais efeitos só poderá ser realizada mediante um horizonte intertemporal mais longo, quando as informaçóes disponíveis sobre o emprego doméstico "antes" e "depois" da lei permitirem captar os efeitos dessas mudanças.

A seção 3.2 deste capítulo discute com mais detalhes duas questôes importantes sobre a legislação das empregadas domésticas. A primeira delas trata da possibilidade que a $\mathrm{LC} \mathrm{n}^{\circ}$ 150/2015 abre para o Codefat regulamentar pontos importantes sobre o seguro-desemprego dos trabalhadores em geral. Por fim, a outra questão trata da elevaçấo significativa do número de segurados da modalidade do trabalhador doméstico em 2014. Mostra-se que essa elevação significativa é possivelmente resultante da $\mathrm{EC}$ nํㅜㄱ․

24. Costa et al. (2015) analisam o impacto da EC no 72 sobre a formalização, a jornada de trabalho e os salários das empregadas domésticas. Os resultados encontrados mostram que a legislação impactou de forma distinta as empregadas domésticas mensalistas e diaristas. Para as mensalistas, observa-se um aumento na formalização e algum indício de redução da jornada de trabalho. No entanto, não se encontra efeito sobre os salários. Para as diaristas, não foi encontrado nenhum efeito. Entretanto, observa-se um aumento na probabilidade de ser diarista, o que poderia estar associado à substituição da empregada mensalista.

25. A seção 3.2 aborda com mais detalhes a questão da obrigatoriedade do Fundo de Garantia do Tempo de Serviço (FGTS). 26. É válido mencionar que a Lei no 12.964 começou a vigorar a partir de agosto de 2014 e prevê cobrança de multas ao empregador doméstico que não assinar a carteira de trabalho do seu empregado.

27. 0 primeiro veto trata sobre a possibilidade de estender o regime de horas previsto na lei, de 12 horas trabalhadas por 36 de descanso, e o segundo, sobre uma das razões para demissão por justa causa, a violação de fato ou circunstância íntima do empregador ou da família.

28. A ferramenta que viabiliza o recolhimento dessas obrigações (Módulo Empregador Doméstico) ficou disponível a partir de 1\%/10/2015 e faz parte do eSocial, projeto do governo federal que visa a unificar o envio de informações pelo empregador em relação aos seus empregados (Disponivel em: <http://www.esocial.gov.br>). 


\subsection{Plano de Proteção ao Emprego: regras impostas pela Medida Provisória no $680 / 2015$}

Como mencionado, desde a metade de 2014, a economia brasileira foi afetada por um clima deletério, relacionado a inúmeros problemas. Um deles tem sido a desaceleração econômica, que provavelmente resultará em uma acentuada contração do PIB em 2015. Na esteira dessa contração, o mercado de trabalho também desacelerou, o que mostra uma dinâmica negativa no que tange ao emprego, ao desemprego e aos rendimentos do trabalho.

Nesse contexto, o governo editou a Medida Provisória no 680/2015, com regras para o chamado Plano de Proteção do Emprego (PPE). ${ }^{29}$ Em linhas gerais, este plano é uma tentativa de minimizar as consequências dessa dinâmica negativa, especificamente em termos de desemprego. Sua finalidade é permitir que as empresas reduzam o tempo de trabalho e o salário e, ao mesmo tempo, mantenham os atuais postos de trabalho.

\subsubsection{0 mecanismo do PPE}

Com este objetivo de preservação dos postos, o PPE pode ser descrito como uma política de trabalho ativa, ao contrário de outras iniciativas, como o seguro-desemprego, que é focado em trabalhadores que perderam os seus postos de trabalho. De qualquer maneira, essa política não é propriamente nova, porque a Constituição de 1988 já havia estabelecido a possibilidade de redução simultânea do tempo de trabalho e do salário. ${ }^{30}$ Além disso, vinte anos antes, a Lei no 4.923/1965 já tinha definido um mecanismo semelhante, a fim de manter postos de trabalho em meio a uma crise econômica. ${ }^{31}$

De acordo com a Medida Provisória no 680/2015, as empresas que enfrentam dificuldades econômicas são elegíveis para o PPE, sendo autorizadas a reduzir temporariamente o tempo de trabalho de todos os seus trabalhadores (ou parte deles), bem como reduzir proporcionalmente o seu salário, até a porcentagem máxima de $30,0 \%{ }^{32}$

29. Posteriormente, essa medida provisória foi regulamentada pelo Decreto ํㅗ 8.479/2015.

30. Constituiç̧ão Federal, Artigo 7ํ, incisos VI (São direitos dos trabalhadores urbanos e rurais, além de outros que visem à melhoria de sua condição social: VI - irredutibilidade do salário, salvo o disposto em convenção ou acordo coletivo') e XIII ('São direitos dos trabalhadores urbanos e rurais, além de outros que visem à melhoria de sua condição social: XIII duração do trabalho normal não superior a oito horas diárias e quarenta e quatro semanais, facultada a compensação de horários e a redução da jornada, mediante acordo ou convenção coletiva de trabalho).

31. Lei no 4.923/1965, Artigo 2o (A empresa que, em face de conjuntura econômica, devidamente comprovada, se encontrar em condiç̃es que recomendem, transitoriamente, a redução da jornada normal ou do número de dias do trabalho, poderá fazê-lo, mediante prévio acordo com a entidade sindical representativa dos seus empregados, homologado pela Delegacia Regional do Trabalho, por prazo certo, não excedente de 3 (três) meses, prorrogável, nas mesmas condições, se ainda indispensável, e sempre de modo que a redução do salário mensal resultante não seja superior a $25 \%$ (vinte e cinco por cento) do salário contratual, respeitado o salário-mínimo regional e reduzidas proporcionalmente a remuneração e as gratificações de gerentes e diretores).

32. Isso não deve resultar em salários com valor inferior ao salário-mínimo nacional. 
No entanto, essa redução simultânea tem de ser parte de um acordo coletivo, assinado por empresas e sindicatos, a fim de conter fraudes e outras situaçóes problemáticas.

De acordo com a medida provisória, a redução do tempo de trabalho e do salário pode durar por seis meses, renováveis por outros seis. E, durante esse período, o Estado paga até metade das perdas dos trabalhadores - em outras palavras, até $15,0 \%$ do seu salário. ${ }^{33}$ Os recursos para isso vêm do Fundo de Amparo ao Trabalhador (FAT), que historicamente proporciona fundos para o seguro-desemprego. Uma das ideias por trás do PPE é justamente essa: em vez de pagar uma subvenção para os trabalhadores desempregados, é melhor pagar um subsídio para aqueles empregados (apesar dos problemas relacionados com as suas perdas salariais).

Há vários requisitos a serem observados pelas empresas, para que possam aderir ao PPE: i) devem ter sido constituídas há pelo menos dois anos; ii) têm de apresentar uma situação regular, no que se refere a impostos e contribuiçôes sociais; iii) devem estar comprovadamente sob estresse econômico; ${ }^{34}$ iv) não estão autorizadas a demitir trabalhadores durante e depois do PPE (até quatro meses após); ${ }^{35}$ v) náo podem contratar trabalhadores para desenvolver as atividades daqueles que sofrem com a redução de tempo de trabalho/salário; vi) têm de esgotar as férias e as licenças de todos os trabalhadores, antes de reduzir seu tempo de trabalho e seu salário; vii) devem chegar a um acordo coletivo com os sindicatos; viii) têm de pagar contribuiçóes sociais sobre o montante do salário pago pelo Estado; ix) apenas as empresas com o chamado "Indicador Líquido de Emprego" (ILE) inferior a $1,0 \%$ podem aderir ao PPE; ${ }^{36}$ xi) em caso de não observância de todos esses requisitos, elas são obrigadas a devolver o montante do salário pago pelo Estado (acompanhado de uma multa).

\subsubsection{Prós e contras do PPE}

Com todos esses requisitos a serem observados pelas empresas, o governo provavelmente pretendeu limitar qualquer risco de desvio de recursos públicos com o PPE. Em que pese a intenção governamental, a lista de requisitos é tão extensa que nem todas as empresas podem ser capazes de aderir a essa iniciativa e, como resultado, nem todos os trabalhadores podem ter seus empregos protegidos. ${ }^{37}$ As projeçóes do Ministério do Trabalho e Emprego (MTE) sobre o alcance do PPE parecem bastante

33. 0 valor deste percentual de 15,0\% tem de ser limitado a 65,0\% do valor máximo pago pelo seguro- desemprego. 34. Informações provando estresse econômico têm de ser enviadas para os sindicatos de trabalhadores com antecedência. 35. Apenas os trabalhadores que sofreram com a redução do salário.

36. O ILE é um indicador com a seguinte fórmula: ([no admissões nos últimos doze meses - no demissões nos últimos doze meses]/[no trabalhadores empregados 13 meses atrás]) * 100,0.

37. Além dos problemas relacionados com o número, há questões relativas aos tipos de empresas capazes de aderir ao PPE. Esta iniciativa é concebida para todas elas ou somente para algumas específicas? Se o último for verdadeiro, o PPE é concebido para pequenas, médias ou grandes empresas? Para empresas industriais, de construção, comerciais ou de serviços? Todas essas questões são colocadas por Zylberstajn, 2015. 
modestas, considerando o rápido aumento no desemprego no período recente. De acordo com essas projeçôes oficiais, essa iniciativa será capaz de proteger os postos de aproximadamente 50 mil trabalhadores, o que representa apenas 3,2\% do número de postos de trabalho (assalariados formais) fechados no ano de 2015, segundo o MTE (2016).

De qualquer forma, antes da crítica sobre seu escopo modesto, há uma crítica sobre a própria razão de ser do PPE. Alguns atores laborais afirmam que o objetivo dessa iniciativa é problemático, porque envolve o pagamento de um subsídio público para a redução do tempo de trabalho e do salário. Eles questionam a razão pela qual o Estado deveria "incentivar" as empresas a enfraquecer (ou mesmo 'precarizar') itens relevantes das regulaçóes laborais, especialmente se considerado que o subsídio é pago com os recursos dos trabalhadores (do FAT). ${ }^{38}$ Outros atores consideram que não há nenhuma razão para a diminuição salarial promovida pelo $\mathrm{PPE}$, porque as empresas já se beneficiam da diminuição do tempo de trabalho (que gera custos menores, devido ao menor tempo de funcionamento de suas instalaçóes). ${ }^{39}$ Finalmente, outros atores afirmam que o PPE é problemático, porque ele surgiu depois de iniciativas como as isençôes de contribuiçôes previdenciárias, recentemente implantadas pelo Estado, que beneficiaram empresas sem quaisquer compromissos em relação a seus níveis de emprego. ${ }^{40}$

Em suma, no debate envolvendo os atores laborais, há uma extensa lista de críticas dirigidas ao PPE. No entanto, há outros atores que consideram essa iniciativa relevante, dados os problemas atuais do mercado de trabalho. De acordo com eles, o PPE é inspirado na regulação laboral alemã. A regulação desse país estimula as negociaçóes entre empresas e trabalhadores, com o apoio financeiro do Estado, para reduzir o tempo de trabalho e o salário, em caso de contração econômica. Ao longo dos anos, essa iniciativa foi adotada por outros países em todo o mundo, com resultados satisfatórios - e o mesmo pode, talvez, acontecer no Brasil a partir de agora. ${ }^{41}$

Além disso, esses mesmos atores afirmam que, dados os atuais problemas do mercado de trabalho, o PPE é a melhor opção disponível para os trabalhadores, as empresas e até mesmo para o Estado. Com a redução subsidiada do tempo de trabalho e do salário, os postos de trabalho não são reduzidos. E, para os trabalhadores, isso é importante, porque eles mantêm a maior parte de seus rendimentos. Para as empresas, isso também é relevante, porque elas mantêm os seus trabalhadores, que serão necessários numa futura retomada econômica. Para o Estado, isso também

38. Sobre essa crítica, ver Villaverde, 2015.

39. Sobre essa crítica, ver Anamatra, 2015.

40. Sobre essa crítica, ver Anamatra, 2015. Sobre essa isenção fiscal, ver Ipea, 2014.

41. Sobre isso, ver Pastore, 2012a; 2012b, 2015. 
é importante, porque ele continua a arrecadar impostos e contribuiçóes sociais, pagos pelos trabalhadores e pelas empresas. ${ }^{42}$

Enfim, apesar de todos esses argumentos, o PPE parece ser bastante modesto, como uma solução para o desemprego que afeta o mercado de trabalho brasileiro. Hoje em dia, provavelmente, a solução não está no domínio de políticas laborais, mas na esfera das políticas econômicas. Afinal de contas, só com a recuperação da economia como um todo - e, especialmente, com a revitalização dos investimentos os postos de trabalho voltarão a ser criados no mercado laboral. ${ }^{43}$

\section{ACOMPANHAMENTO DA POLÍTICA E DOS PROGRAMAS}

\subsection{Fundo de Amparo ao Trabalhador (FAT) e Execução Orçamentária do Ministério do Trabalho e Emprego (MTE)}

$\mathrm{Na}$ tabela 1, pode-se observar que o resultado nominal do $\mathrm{FAT}^{44}$ em 2014, em valores atualizados, ${ }^{45}$ foi de cerca de $\mathrm{R} \$ 851,4$ milhóes, um resultado bem melhor que o déficit de $\mathrm{R} \$ 11,5$ bilhóes em 2013. As receitas do FAT cresceram quase $23 \%$ em termos reais no referido ano, enquanto os gastos com as obrigaçóes do fundo aumentaram apenas $1,8 \%$.

Pelo lado das receitas, esse aumento ocorreu tanto nas receitas primárias quanto nas receitas financeiras e nos repasses do Tesouro Nacional para o fundo. Nos dois primeiros itens, houve uma reversão do crescimento negativo verificado em 2013. No caso das receitas financeiras, a mudança foi causada pela reversão do desempenho negativo das aplicações no extramercado, em 2013, para o padrão positivo dos anos anteriores. Já as receitas primárias cresceram $6,6 \%$ em termos reais, o que, embora positivo, está abaixo da taxa média de crescimento do período 2003-2011, de cerca de 9\% a.a. É sabido que a Desvinculaçâo de Recursos da Uniāo (DRU) - e suas versões anteriores - subtrai recursos do FAT desde 1994 em um montante que chegou a $\mathrm{R}$ \$ 10,4 bilhôes, em 2014. Mas esse problema foi reforçado pelo aumento das desonerações do PIS/Pasep feitas nos últimos anos. ${ }^{46}$ Em 2007, as desoneraçóes retiravam cerca de $\mathrm{R} \$ 2,3$ bilhóes do FAT, o que passou para R \$ 5 bilhóes, em 2008, e alcançou R \$ 11,6 bilhóes, em 2014.

42. Outra vantagem do PPE, do ponto de vista do Estado, é que com ele não há necessidade de pagar seguro desemprego para trabalhadores desempregados. Sobre isso, ver Pastore, 2012a; 2012b, 2015.

43. Sobre isso, ver Dedecca, 2015.

44. 0 resultado nominal do FAT é definido pela diferença entre o total das receitas do FAT (que incluem aquelas advindas da arrecadação do Programa de Integração Social/Programa de Formação do Patrimônio do Servidor Público (PIS/Pasep), as receitas financeiras e outras entradas de recursos) e o montante da soma das despesas correntes do fundo - que incluem os gastos obrigatórios com o seguro-desemprego e o abono salarial, mais aqueles com os programas de qualificação profissional e de intermediação de mão de obra - com o valor dos repasses do FAT ao Banco Nacional de Desenvolvimento Econômico e Social (BNDES), no âmbito do determinado pelo Artigo 239 da Constituição Federal de 1988. 45. Nesta seção, o deflator utilizado para calcular os valores reais foi o IPCA.

46. Os dados sobre os recursos perdidos pela desoneração do PIS/Pasep, que serão citados a seguir, foram extraídos do Relatório de Gestão do FAT - 2014. 
Por sua vez, os repasses do Tesouro aumentaram 70\% em termos reais em 2014, chegando a $\mathrm{R} \$ 11,9$ bilhóes, o montante mais alto já registrado. Essa quantia foi fundamental para que o FAT pudesse cumprir os compromissos com o pagamento do seguro-desemprego e do abono. Antes disso, chegou a ser considerada a hipótese de se recorrer aos recursos do FAT no BNDES no âmbito do FAT Constitucional. ${ }^{47}$

Pelo lado das obrigaçóes, o resultado veio de um arrefecimento do crescimento real dos gastos com o seguro $(6 \%$, em 2014 , contra uma média de $9 \%$, nos três anos anteriores) e no abono ( $1,8 \%$, em 2014 , contra um crescimento superior a $10 \%$, nos três anos anteriores). Houve também uma queda dos repasses para o BNDES devido a atrasos. Como foi discutido nas seçóes anteriores deste capítulo, os programas do seguro-desemprego e do abono foram modificados com vista a reduzir os gastos.

\section{TABELA 1}

Entradas e saídas do Fundo de Amparo ao Trabalhador (2012-2014) (R\$ Milhões)'

\begin{tabular}{|c|c|c|c|}
\hline Orçamento do FAT & 2012 & 2013 & 2014 \\
\hline \multicolumn{4}{|l|}{ Receitas } \\
\hline 1. Receita primária (PIS-Pasep) & $42.671,53$ & $40.417,58$ & $43.107,15$ \\
\hline 2. Receitas Financeiras: & $16.293,16$ & $8.820,46$ & $12.695,34$ \\
\hline 3. Outras Receitas: & $6.982,31$ & $7.798,85$ & $14.307,58$ \\
\hline 3.1 Transferência recursos ordinários Tesouro & $5.966,87$ & $7.004,02$ & $11.909,97$ \\
\hline 3.2 Outras & $1.015,44$ & 794,82 & $2.397,61$ \\
\hline Total das entradas $(A=1+2+3)$ & $65.947,00$ & $57.036,89$ & $70.110,07$ \\
\hline \multicolumn{4}{|l|}{ Obrigações } \\
\hline 1. Despesas constitucionais: & $45.022,81$ & $49.544,19$ & $51.832,55$ \\
\hline 1.1 Seguro-desemprego & $31.119,92$ & $33.946,16$ & $35.955,81$ \\
\hline 1.2 Abono-salarial & $13.902,89$ & $15.598,03$ & $15.876,74$ \\
\hline 2. Outras despesas: & 598,28 & 528,57 & 519,51 \\
\hline 2.1 Intermediação de mão de obra (Sine) & 158,89 & 124,68 & 138,69 \\
\hline 2.2 Qualificação profissional & 65,83 & 7,04 & 0,50 \\
\hline 2.3 Outras despesas & 373,56 & 396,85 & 380,32 \\
\hline \multicolumn{4}{|l|}{ 3. Despesas de capital: } \\
\hline 3.1 Empréstimos ao BNDES: (2) & $16.973,66$ & $17.993,69$ & $16.906,77$ \\
\hline Total das obrigações $(B=1+2+3)$ & $62.594,75$ & $68.066,45$ & $69.258,82$ \\
\hline Resultado nominal (A - B) & $3.352,26$ & $-11.029,56$ & 851,24 \\
\hline
\end{tabular}

Fonte: CGFAT/MTE, Siafi/Sidor (2013-2015).

Elaboração da Disoc/lpea.

Nota: ${ }^{1}$ Valores deflacionados pelo IPCA de 2014.

47. Ver Ata da 124a Reunião Ordinária do Codefat. 
Como visto em várias ediçóes anteriores deste periódico, o aumento dos gastos com o seguro e o abono está restringindo os recursos disponíveis para os programas de geração de emprego e renda - que são repassados por meio de depósitos especiais. Diante disso, mencionou-se na edição anterior deste periódico que, em 2014, o Codefat decidiu, por meio da Resolução n⿳o 727, investir $\mathrm{R} \$ 3,5$ bilhôes em depósitos especiais no âmbito de programas de geração de emprego e renda, beneficiando as micro e pequenas empresas em detrimento das empresas maiores, dado o maior potencial do primeiro grupo para gerar mais empregos. Mais tarde, foi editada a Resolução no 734, que aumentou esse montante para $\mathrm{R} \$$ 3,6 bilhóes. $\mathrm{O}$ montante mencionado é o maior desde 2009, ainda que muito abaixo da média 2002-2008 ( $\mathrm{R} \$ 9$ bilhōes, em termos nominais).

Para conseguir isso, no atual contexto de restriçôes, o Codefat, além de recorrer ao excedente da Reserva Mínima de Liquidez (RML), como é o usual, decidiu antecipar o Reembolso Automático (RA) de recursos dos depósitos especiais que estavam no BNDES alocados no FAT Infraestrutura e no FAT Exportar, programas destinados a empresas maiores, suspendendo os repasses para o primeiro ao longo de 2014 e extinguindo o segundo. Um dos argumentos para sustentar essa decisão foi o exposto no Artigo 9º da Lei no 8.019/1990 (com redação dada pela Lei no 8.352/1991), que diz que os depósitos especiais estáo disponíveis para "imediata movimentaçáo" por parte do FAT, tese que foi apoiada por um parecer da Advocacia-Geral da União (AGU). Em resposta, o departamento jurídico do BNDES argumentou, em linhas gerais, que a decisão do Conselho contradiz os princípios da boa-fé objetiva, com quebra de confiança entre as partes e abalo da segurança jurídica, uma vez que o Banco tinha a expectativa de continuar aplicando os recursos do FAT no FAT Infraestrutura e no FAT Exportar. ${ }^{48}$ No fim, o Codefat aprovou a Resolução no 734, já mencionada.

Para 2015, o Codefat propôs um novo esforço para tentar impulsionar os programas de geração de emprego e renda aprovando uma Programação de Depósitos Especiais (PDE) no montante total de R \$ 3,7 bilhóes. ${ }^{49}$ Para isso, além de usar o excedente da Reserva Mínima de Liquidez (RML), ele suspendeu definitivamente repasses para o FAT Infraestrutura. A distribuição de recursos aprovada foi: i) FAT Fomentar: R\$ 1,6 bilhão; ii) FAT PNMPO (Programa Nacional de Microcrédito Produtivo Orientado): R \$ 260 milhóes; iii) Pronaf: R \$ 600 milhôes; d) Proger Urbano ${ }^{50}$ : R \$ 1,1 bilhão; f) FAT Taxista: R 140 milhóes.

48. Na edição anterior deste periódico, foi mostrada a distribuição dos recursos aprovados na PDE 2014 entre os programas. A mudança mais importante que houve foi a suspensão do repasse ao FAT Inovacred, executado pela Finep, que não cumpriu alguns requisitos formais para o seu recebimento. Os recursos desse programa foram para o Proger. 49. Ver Ata da 128a Reunião do Codefat e a Resolução do Codefat no 740.

50. Dentro do Proger Urbano, em 2015, foram destinados $R \$ 1,070$ bilhão para o Proger Investimento e $R \$ 30$ milhões para o Proger Exportação. Além disso, o Proger passou a incluir linhas pró setor turismo, fazendo com que o FAT Turismo deixasse de existir como um programa individual. 
TABELA 2

Volume e nível de execução orçamentária do MTE em 2013 e 2014, segundo programas e ações selecionados do PPA (2012-2015)

$(E m R \$)^{1}$

\begin{tabular}{|c|c|c|c|c|}
\hline \multirow{2}{*}{$\begin{array}{l}\text { Programas e ações selecionados - } \\
\text { PPA 2012-2015 }\end{array}$} & \multicolumn{2}{|c|}{2013} & \multicolumn{2}{|c|}{2014} \\
\hline & Liquidado* & $\begin{array}{c}\text { Nível de } \\
\text { execução (\%) }\end{array}$ & Liquidado* & $\begin{array}{l}\text { Nível de } \\
\text { execução (\%) }\end{array}$ \\
\hline Ministério do Trabalho e Emprego & 71.245 .070 .063 & 94,80 & 72.312 .690 .635 & 93,83 \\
\hline $\begin{array}{l}\text { Desenvolvimento regional, territorial } \\
\text { sustentável e economia solidária }\end{array}$ & 77.308 .953 & 75,50 & 67.735 .962 & 80,96 \\
\hline $\begin{array}{l}\text { Fomento e fortalecimento de } \\
\text { empreendimento econômicos solidários } \\
\text { e suas redes de cooperação }\end{array}$ & 60.401 .849 & 73,40 & 41.442 .156 & 73,13 \\
\hline $\begin{array}{l}\text { Fortalecimento da institucionalização da } \\
\text { política nacional de economia solidária }\end{array}$ & 16.907 .104 & 85,89 & 26.293 .806 & 97,38 \\
\hline Autonomia e emancipação da juventude & 74.172 .380 & 52,03 & 9.181 .050 & 6,04 \\
\hline Concessão de auxílio-financeiro & 23.409 .676 & 73,80 & 7.019 .800 & 24,54 \\
\hline $\begin{array}{l}\text { Elevação da escolaridade e qualificação } \\
\text { profissional - ProJovem Urbano e Campo }\end{array}$ & 50.762 .705 & 45,80 & 2.161 .250 & 1,75 \\
\hline Trabalho, emprego e renda & 49.897.363.865 & 98,98 & 52.150 .872 .264 & 99,85 \\
\hline $\begin{array}{l}\text { Bolsa de qualificação profissional } \\
\text { para trabalhador com contrato } \\
\text { de trabalho suspenso }\end{array}$ & 35.987 .662 & 76,63 & 56.976 .461 & 94,94 \\
\hline Pagamento do benefício abono salarial & 15.598 .026 .379 & 99,27 & 15.876.742.344 & 100,00 \\
\hline Pagamento do seguro-desemprego & 31.858 .640 .176 & 100,00 & 33.462 .018 .859 & 100,00 \\
\hline $\begin{array}{l}\text { Pagamento do seguro-desemprego } \\
\text { ao pescador artesanal }\end{array}$ & 2.012.947.637 & 96,56 & 2.399 .659 .373 & 100,00 \\
\hline $\begin{array}{l}\text { Pagamento do seguro-desemprego } \\
\text { ao trabalhador doméstico }\end{array}$ & 34.414 .794 & 98,14 & 33.962 .338 & 83,73 \\
\hline $\begin{array}{l}\text { Pagamento do seguro-desemprego } \\
\text { ao trabalhador resgatado de } \\
\text { condição análoga à de escravo }\end{array}$ & 4.169.789 & 61,61 & 3.192 .086 & 63,04 \\
\hline $\begin{array}{l}\text { Manutenção, modernização e ampliação } \\
\text { da rede de atendimento do programa } \\
\text { do seguro-desemprego no âmbito do } \\
\text { Sistema Nacional de Emprego (Sine) }\end{array}$ & 124.675 .940 & 59,87 & 138.688 .345 & 94,35 \\
\hline $\begin{array}{l}\text { Fiscalização de obrigaç̃̃es trabalhistas e } \\
\text { inspeção em segurança e saúde no trabalho }\end{array}$ & 28.834 .786 & 82,85 & 24.693 .189 & 84,31 \\
\hline Democratização das relações de trabalho & 901.219 & 51,61 & 1.244 .095 & 88,86 \\
\hline $\begin{array}{l}\text { Produção e difusão de conhecimentos } \\
\text { para a promoção de políticas públicas } \\
\text { em segurança e saúde no trabalho }\end{array}$ & 4.686 .943 & 93,73 & 4.691 .650 & 95,75 \\
\hline $\begin{array}{l}\text { Cadastros públicos na área } \\
\text { de trabalho e emprego }\end{array}$ & 34.116 .937 & 70,59 & 28.282 .792 & 99,51 \\
\hline $\begin{array}{l}\text { Estudos, pesquisas e geração de informações } \\
\text { sobre trabalho, emprego e renda }\end{array}$ & 6.142 .301 & 34,81 & 13.278 .292 & 74,50 \\
\hline
\end{tabular}


(Continuação)

\begin{tabular}{|c|c|c|c|c|}
\hline \multirow{2}{*}{$\begin{array}{l}\text { Programas e ações selecionados - } \\
\text { PPA 2012-2015 }\end{array}$} & \multicolumn{2}{|c|}{2013} & \multicolumn{2}{|c|}{2014} \\
\hline & Liquidado* & $\begin{array}{c}\text { Nível de } \\
\text { execução (\%) }\end{array}$ & Liquidado* & $\begin{array}{c}\text { Nível de } \\
\text { execução (\%) }\end{array}$ \\
\hline $\begin{array}{l}\text { Qualificação social e profissional } \\
\text { de trabalhadores }\end{array}$ & 7.040 .418 & 5,04 & 500.000 & 2,20 \\
\hline Outras ações & 146.778 .883 & 69,46 & 106.942 .440 & 79,76 \\
\hline Outros programas finalísticos & 55.880 .404 & 96,00 & 60.379 .910 & 97,78 \\
\hline Programas não finalísticos & 21.140 .344 .460 & 86,50 & 20.024.521.449 & 81,59 \\
\hline
\end{tabular}

Fonte: Execução Orçamentária e Financeira da União/Câmara dos Deputados, 2013 e 2014.

Elaboração da Disoc/lpea.

Notas: ${ }^{1}$ Os valores de 2013 foram deflacionados pelo IPCA de 2014.

Quanto à execução orçamentária de programas e açôes selecionados dentro do Ministério do Trabalho e Emprego, sua síntese consta da tabela 2. No caso das obrigaçóes do FAT - seguro e abono -, houve um crescimento nos gastos como um todo. Quando o programa do seguro por modalidade foi examinado, houve continuidade do crescimento, em termos reais, das modalidades "formal" ( $5 \%$, contra $10 \%$ no ano anterior). Por sua vez, outras modalidades do seguro apresentaram mudança de direção na sua taxa de crescimento real: no caso do seguro do pescador artesanal, a queda de $4,7 \%$, em 2013 , foi seguida por um crescimento de 19,2\%, em 2014; no caso da modalidade "trabalhador doméstico" o aumento de $12,3 \%$, em 2013, foi seguido por uma queda de 1,3\%, em 2014. Por fim, os gastos com o seguro-desemprego para o trabalhador libertado da condição de escravo continuaram a sua trajetória de queda de gastos, que ocorreu a uma taxa de 23,4\%, em 2014. Alguns destes movimentos no programa do seguro-desemprego serão discutidos mais à frente. No caso do abono, o contínuo crescimento dos gastos continua a ocorrer, ainda que, em 2014, o ritmo tenha caído consideravelmente, como se verá na próxima seção.

Em suma, o que se pode dizer quanto à situação do FAT é que, como se previa, ele está se tornando mais dependente de recursos do Tesouro Nacional e, cada vez mais, está se dirigindo exclusivamente para o pagamento do seguro-desemprego e do abono. Para melhorar isso, está se contando com o fim da DRU e uma reversão no processo de desoneraçóes do PIS/Pasep. Quanto ao primeiro, não será fácil que ocorra. Por sua vez, o segundo cenário parece mais possível.

Outro aspecto importante a se tirar da análise é a tentativa do Codefat de dar um impulso para os programas de geração e renda, concluindo o processo de enxugamento do grande número de programas criados em 2005 e 2006. A interrupção do FAT Infraestrutura simboliza a volta aos objetivos originais dos depósitos especiais quando da criação do Proger em 1994: apoiar micro e pequenas empresas, dado que elas têm menos acesso aos meios de financiamento convencionais e têm maior potencial de geração de empregos. Ao mesmo tempo, os recursos destinados 
ao BNDES pelo FAT Constitucional continuarão a ser uma fonte de recursos para incentivar grandes projetos: por exemplo, em 2014, 38\% desses recursos foram desembolsados em projetos na área de infraestrutura.

\subsection{Programas de garantia de renda: seguro-desemprego e abono salarial}

Em 2014, foram gastos cerca de R \$ 35,9 bilhóes com o pagamento dos benefícios do Programa do Seguro-Desemprego em todas as suas modalidades, um montante cerca de $6 \%$ superior em termos reais ao resultado de 2013. Já o número de segurados atendidos pelo programa em todas as suas modalidades passou de cerca de 9,2 milhóes, em 2013, para 9,4 milhóes, em 2014, ${ }^{51}$ com uma taxa de crescimento de 2,7\%. Foi um crescimento abaixo da média do período 2005-2013 - de quase 7\%.

Esse aumento foi impulsionado pelo crescimento das duas principais modalidades do programa: o seguro-desemprego formal e o seguro-defeso. No primeiro, havia 8,3 milhóes de segurados, em 2013, e quase 8,5 milhóes, em 2014, enquanto na segunda modalidade havia 811 mil segurados, em 2013, e 874 mil, em 2014, em ambos os casos, verificou-se um aumento abaixo da média recente. Deve-se destacar, por outro lado, que duas modalidades pequenas dentro do programa também cresceram significativamente acima do seu padrão histórico, em 2014: o seguro do trabalhador doméstico e a bolsa-qualificação.

Quanto aos fatores que podem influenciar o número de segurados da modalidade formal, os mais importantes nos últimos anos foram a formalização e o aumento real do salário-mínimo. Porém, principalmente no caso da formalização, esses movimentos estáo perdendo força. Por exemplo, o Caged mostrou que o saldo de empregos formais em 2014 caiu de cerca de 730 mil postos para cerca de 152 mil, enquanto essa mesma variável para o período de janeiro a julho de 2015 já está com um resultado negativo de cerca de 547 mil. Um olhar mais detido sobre o resultado de 2015 - comparado ao mesmo período do ano anterior - mostra que, curiosamente, o número de demitidos sem justa causa manteve-se praticamente estável e o número total de desligados caiu 6,4\%. Portanto, o grande problema da queda da geração de empregos formais veio da queda de $14,4 \%$ no número de admissóes. Assim, num contexto de alta rotatividade de mão de obra, a narrativa da geraçáo de empregos formais como causa para o aumento do número de pessoas demitidas com direito ao seguro pode estar sendo interrompida.

É neste contexto macroeconômico e de mercado de trabalho - colocado aqui e na seção anterior - que foi aprovada a Lei no 13.134 , de 16 de junho de 2015 , que restringe o acesso ao seguro-desemprego e ao abono salarial. Tal lei é descendente da Medida Provisória no 665, de 30 de dezembro de 2014, já comentada

51. Todos os dados físicos do seguro-desemprego citados nesta seção foram extraídos em agosto de 2015. Já os dados financeiros citados, usaram como fonte os relatórios financeiros do FAT. 
anteriormente na seção 2.3 deste capítulo. A Lei no 13.124 basicamente diferenciou as condiçóes de acesso ao benefício entre a primeira, a segunda e a terceira solicitação. Como resultado, elevou-se o tempo de trabalho no setor formal necessário para se ter acesso ao benefício. No entanto, a mudança determinada pela Lei $\mathrm{n}^{-} 13.134$ ocorreu numa escala menor do que a proposta originalmente trazida pela MP no 665 .

A edição da Medida Provisória no 665 motivou alguns trabalhos que procuraram medir seu impacto sobre o número de segurados da modalidade formal. Em um deles, Borges e Fernandes (2015), por exemplo, fizeram um exercício em que calcularam que 2,2 milhóes de trabalhadores seriam impactados com a mudança nas exigências para requerimento do benefício. Tal montante equivaleria a $26,6 \%$ do total de requerentes no ano de 2014. Em outro exercício, os autores calcularam que a referida MP ajudaria a economizar quase R 99 bilhóes dos gastos com o seguro em 2014, o que coincide com o valor mencionado na edição anterior, como o objetivo de diminuição de gastos com o seguro por parte do governo ao editar a MP no 665 . A aprovação da Lei oํ 13.134, obviamente, diminuirá este montante economizado. De qualquer forma, esse tema ainda motivará muitos estudos.

Pelo lado da gestão, a Resolução do Codefat no 736 , de 8 de outubro de 2014, havia determinado que os empregadores seriam obrigados a utilizar o aplicativo "Empregador Web" 52 - que será a nova forma pela qual será providenciado o requerimento do seguro-desemprego, colocando esta tarefa a cargo do empregador a partir de 31 de março de 2015. Porém, o Codefat depois decidiu, por meio da Resoluçáo no 742, de 31 de março de 2015, adiar o prazo para o final de 2015, deixando claro que o referido aplicativo será a única forma aceita de se fazer o requerimento do seguro. Ao mesmo tempo, o Conselho resolveu determinar a elaboração de relatórios gerenciais para acompanhar o grau de adesão à ferramenta.

O número de segurados na modalidade "pescador artesanal", depois de ter apresentado uma queda incomum em 2013, voltou a subir em 2014, passando de 811 mil para quase 874 mil. O seguro-defeso continua a ter evidências de fraudes, que vêm sendo investigadas. Por exemplo, o Tribunal de Contas de União (TCU), em 2015, apontou indícios de pagamentos indevidos do benefício, entre janeiro de 2012 e junho de 2013, no valor de $\mathrm{R} \$ 19,5$ milhóes.

O seguro-defeso, assim como a modalidade formal, também sofreu mudanças nas suas normas, primeiro pela MP no 665 , e depois pela Lei $n^{\circ} 13.134$, já comentadas anteriormente. As medidas tomadas para o seguro-defeso podem contribuir para dificultar as fraudes, tocando em aspectos que eram frágeis no que diz respeito ao cadastramento do pescador artesanal, como, por exemplo, a questáo de o direito ser extensível a atividades de apoio à pesca e aos familiares do pescador artesanal. De qualquer forma, é fundamental que o esforço de fiscalizar o pagamento do 
seguro do pescador artesanal seja mantido, sob pena de não se conseguir a economia de recursos que se espera.

No que se refere ao seguro-desemprego das trabalhadoras domésticas, o fato mais relevante foi a regulamentação da Emenda Constitucional no $72 / 2013$ pela Lei Complementar no 150 , de $1^{\circ}$ de junho de 2015, que também tratou da questáo do seguro-desemprego dos trabalhadores domésticos. ${ }^{53}$ Como já discutido na seção 2.4 , uma determinação fundamental da referida lei foi a obrigatoriedade da contribuição do empregador para o FGTS da doméstica. Isto porque na Lei no 10.208, de 23 de março de 2001, que criou o programa, havia a exigência de apresentação de comprovante de recolhimento do FGTS, sendo que tal recolhimento não era obrigatório para o empregador - aliás, essa exigência não existia no seguro-desemprego formal. Porém, com a nova legislação, essa barreira simplesmente deixou de existir.

A Lei Complementar no 150 abriu a possibilidade do Codefat regulamentar dois pontos importantes do seguro-desemprego do trabalhador: i) o período de trabalho necessário para poder requerer o benefício; e ii) o período de carência entre os benefícios.

Para o item $i$, a exigência atual é de um período de 15 meses nos últimos 24 meses, enquanto, para o item $i i$, a carência é de 16 meses (igual ao do seguro-desemprego formal).

As primeiras discussóes do Codefat indicam uma tendência de manter essas regras, mas pode ser possível, por exemplo, determinar que o período de trabalho necessário para requerer o seguro seja de doze meses nos últimos dezoito, na primeira solicitação, assim como determinado pela Lei no 13.134 para o trabalhador formal. Isso diminuiria as diferenças entre os programas para a trabalhadora doméstica e para o empregado formal. Por outro lado, existem diferenças entre os dois programas que não podem ser alteradas diante do expresso pela Lei Complementar n⿳o 150 , tais como a fixação do benefício da trabalhadora doméstica em um salário-mínimo e do período de recebimento do seguro em três meses.

Quanto ao número de segurados da modalidade do trabalho doméstico, depois de uma alteração pequena, em 2013, houve um notável crescimento de $14,3 \%$, em 2014, com o referido número chegando a 17.665. Essa foi a maior taxa de crescimento já experimentada pelo programa desde 2003, quando ele ainda estava em implementação. Já o valor pago em benefícios, depois de um crescimento real de 11,6\%, em 2013, cresceu apenas 2\%, em 2014. Portanto, o aumento de $19 \%$ nos gastos com essa modalidade de seguro foi, desta vez, mais puxado pelo aumento do número de segurados. É possível que esse resultado tenha sido causado pelos progressos já trazidos pela EC no 72 e pela expectativa de sua regulamentação.

53. Uma melhor discussão da regulamentação dos direitos dos trabalhadores domésticos foi feita anteriormente, na seção 2 deste capítulo. Nesta seção, serão tratados apenas os temas concernentes ao seguro-desemprego do trabalhador doméstico. 
Agora que esta ocorreu, há uma clara perspectiva de crescimento do número de segurados do programa nos anos seguintes.

Por fim, quanto ao programa do abono salarial, o gasto do FAT com o pagamento do benefício, em 2014, foi de cerca de R \$ 15,9 bilhóes, o que representou um aumento real de apenas $1,8 \%$ em relaçáo a 2013. Essa taxa de crescimento real está bem abaixo da média dos anos anteriores, que é superior a $10 \%$, o que acompanhou o crescimento real menor do salário-mínimo. No exercício de 2014 , o abono foi recebido por 22,3 milhóes de trabalhadores, um número $4,9 \%$ maior do que no ano anterior. No ano financeiro do abono 2013-2014, a taxa de cobertura do benefício foi de $95,03 \%$, praticamente igual à média dos últimos dez anos (95,05\%).

O número de trabalhadores com vínculos ativos em 31/12, com base na Rais, que ganham até dois salários-mínimos (um dos critérios para se receber o abono salarial), foi de 26,4 milhōes em 2014, contra 26,8 milhóes em 2013, ou seja, houve uma queda de $1,6 \%$. Foi a primeira queda neste montante ao longo do período 2002-2014. O resultado para esse mesmo universo, mas entre aqueles que não tinham vínculo ativo em 31/12, foi de cerca de 18,8 milhões, em 2014 e 2013, mas com uma taxa de crescimento ligeiramente negativa de $0,5 \%$ - a primeira redução, ainda que ligeira, observada no período 2002-2014. Em ambos os casos, houve um decréscimo da participação do grupo de trabalhadores que ganham até dois salários-mínimos no total de vínculos formais da Rais. Isso reforça a perspectiva de que a desaceleração do crescimento da formalização do mercado de trabalho brasileiro possa repercutir em uma demanda menor pelo abono salarial.

$\mathrm{Na}$ edição anterior deste periódico, foi mencionado que a $\mathrm{MP} \mathrm{n}^{\circ}$ 665, no tocante ao abono, havia determinado duas grandes mudanças: $i)$ a necessidade de que o beneficiário tivesse tido uma atividade remunerada por pelo menos 180 dias ininterruptos, bem acima dos trinta dias consecutivos ou não da regra atual; e ii) a determinação de que o valor do benefício fosse proporcional ao número de meses trabalhados no ano, com o valor do salário-mínimo sendo apenas o valor máximo do benefício em vez de ser o valor fixo. Porém, a Lei no 13.134 manteve apenas a primeira modificação.

Assim, a bancada do governo no Codefat, no momento da votação do cronograma do pagamento do abono para o exercício 2015/2016, propôs que tal pagamento começasse a ocorrer, dependendo do aniversário do beneficiário, no período de julho de 2015 a março de 2016. O objetivo claro dessa proposta foi fazer um ajuste financeiro que reduzissem os gastos com o abono em 2015. Isso porque, embora o exercício financeiro do abono se estenda de julho de um ano a junho do ano seguinte, os benefícios tinham seu pagamento iniciado no mesmo ano do início do exercício. Por exemplo, se o padrão histórico fosse seguido, todos os beneficiários poderiam receber o benefício ainda em 2015 . 
A proposta do governo ganhou a votação no Codefat, tornando-se a Resolução no 748 , de 2 de julho de 2015. Uma compensação foi que aqueles que começariam a receber o benefício em 2016 o fariam pelo valor do salário-mínimo do referido ano. A bancada dos trabalhadores protestou contra o resultado da votação e tem tentado, ainda sem sucesso, rediscutir a proposta.

\subsection{Programas que ofertam serviços: intermediação de mão de obra}

Assim como as transferências de seguro-desemprego e abono salarial, os serviços de intermediação e qualificação ocupacional dirigem-se principalmente ao trabalhador em situação de desemprego, involuntário e temporário. ${ }^{54}$ Enquanto as transferências asseguram um rendimento que permite a subsistência desse trabalhador, os serviços possibilitam que ele consiga uma nova ocupação.

Os serviços de intermediação, em especial, dedicam-se ao trabalhador que está desempregado por conta da assimetria (ou da insuficiência) de informaçáo, entre quem oferta e quem demanda trabalho no mercado laboral. Ou seja, tais serviços procuram colocar em contato o trabalhador desempregado (que oferta) e as empresas (que demandam trabalho), que não possuem informaçôes uns dos outros (ou as têm em grau insuficiente).

O espaço para a atuação dos serviços de intermediação varia bastante, conforme o ciclo da economia. Em momentos de ciclo de baixa, o mercado laboral conta com poucas vagas de trabalho, deixando pouco espaço para a atuação de tais serviços, que incidem essencialmente sobre o desemprego decorrente da assimetria de informação. Já durante o ciclo de alta da economia, há muitas vagas disponíveis no mercado laboral, abrindo bastante espaço para os serviços de intermediação.

O ciclo experimentado pela economia brasileira nos anos 2000, quando o PIB cresceu a taxas relativamente aceleradas, assim como o número de vagas de trabalho, abriu espaço para esses serviços. Ocorre que tal espaço foi apenas parcialmente aproveitado, devido a problemas de diversas naturezas, descritos sumariamente a seguir.

1) De forma histórica, os trabalhadores desempregados no Brasil tendem a procurar novas ocupaçóes por meios pessoais (indicaçóes de amigos e parentes, contatos diretos com empregadores, i.e.), e não por meios institucionais (agências públicas e privadas de intermediação, i.e.). ${ }^{55}$

54. Os serviços de intermediação que são o foco desta seção são os serviços públicos, organizados em torno do Sine (Sistema Nacional de Emprego), que se dedicam principalmente (ainda que não só) à intermediação do trabalho assalariado registrado (ou seja, à intermediação do emprego formal). 0 Sine possui uma estrutura colaborativa, envolvendo diversos entes federados (estados e municípios), mas é coordenado e gerido pelo governo federal - mais especificamente, pelo Ministério do Trabalho e Emprego (MTE). O Sine possui por volta de 1,6 mil agências públicas, espalhadas por quase todo o território nacional, que são um ponto de articulação de todas as políticas laborais, sejam elas transferências ou serviços. Sobre isso, ver Azeredo, 1998; Barbosa e Moretto, 1998; Cardoso Jr. et al., 2006; Moretto, 2007.

55. Sobre isso, ver Guimarães, 2004. 
2) Dentro dos meios institucionais de intermediação, as agências públicas demonstram, historicamente, dificuldades para mapear vagas de trabalhodificuldades que, por outro lado, não existem para mapear trabalhadores desempregados (principalmente, aqueles de baixa qualificação e baixos rendimentos). ${ }^{56}$

3) As agências públicas apresentam, de maneira histórica, dificuldades para atuar em segmentos de intermediação que contam com a atuação de muitas agências privadas (segmentos em que se destacam os trabalhadores desempregados de média e alta qualificação, bem como de média e a alta renda). ${ }^{57}$

Diante de todos esses problemas, mesmo na década de 2000, quando a economia se expandiu, junto com o número de vagas, os serviços de intermediação encontraram dificuldades para ampliar sua relevância no mercado laboral. As taxas de admissão, que contrastam o número de colocados pela intermediação e o número de admitidos no conjunto do mercado, mantiveram-se, na maior parte do tempo, em torno de apenas 5\%.

Isso não significa que os serviços de intermediação não desempenhem um papel relevante junto a segmentos específicos (e mesmo alguns segmentos expressivos) do mercado laboral. Para os trabalhadores com pouca qualificação e pouca renda (insuficiente para pagar por serviços privados), a intermediação realizada pelas agências públicas mostra-se, historicamente, bastante importante. Trata-se de um papel promotor da equidade no mercado laboral, que não deve ser desprezado de maneira alguma.

De toda forma, os dados que constam das tabelas 1 e 2 mostram que a relevância dos serviços de intermediação continua a ser bastante limitada no conjunto do mercado de trabalho. Para o Brasil como um todo, os valores da tabela 2 indicam que as taxas de admissão fixaram-se em níveis inferiores a 5\% no período mais recente (inclusive com uma redução entre 2013 e 2014).

Outros aspectos dos serviços de intermediação também podem ser estudados com os dados das tabelas 3 e 4 . As taxas de efetividade comparam o número de trabalhadores colocados e o número de trabalhadores inscritos nesses serviços, situando-se em torno de $13 \%$ no período recente (com uma leve redução entre 2013 e 2014). Em outras palavras, somente um sétimo dos trabalhadores que procuram os serviços de intermediação consegue uma colocação. 
TABELA 3

Números nacionais e regionais da intermediação pública de trabalho, realizada no âmbito do Sine (2013 e 2014)

(Em números absolutos - mil)

\begin{tabular}{lrrrrrr}
\hline 2013 & Brasil & N & NE & CO & SE & S \\
\hline Inscritos & 6.055 & 352 & 1.090 & 503 & 3.067 & 1.042 \\
Vagas & 3.597 & 106 & 454 & 299 & 2.093 & 644 \\
Colocados & 839 & 41 & 222 & 81 & 293 & 202 \\
Admitidos & 20.942 & 870 & 2.825 & 1.838 & 11.044 & 4.365 \\
\hline 2014 & Brasil & N & NE & CO & SE & S \\
\hline Trabalhos inscritos & 5.185 & 317 & 975 & 437 & 2.527 & 928 \\
Vagas & 2.601 & 110 & 441 & 240 & 1.262 & 549 \\
Trabalhos colocados & 676 & 36 & 203 & 68 & 177 & 191 \\
Trabalhos admitidos & 19.523 & 882 & 2.072 & 1.480 & 10.776 & 4.315 \\
\hline
\end{tabular}

Fonte: MTE/SPPE, 2013 e 2014.

Elaboração dos autores.

\section{TABELA 4}

Indicadores nacionais e regionais da intermediação pública de trabalho, realizada no âmbito do Sine (2013 e 2014)

(Em números relativos - \%)

\begin{tabular}{lcccccccc}
\hline 2013 & Brasil & N & NE & CO & SE & S & Desvio-padrão $^{4}$ & Coeficiente de variação $^{5}$ \\
\hline Taxa efetividade $^{1}$ & 13,9 & 11,6 & 20,4 & 16,1 & 9,5 & 19,4 & 4,2 & 27,5 \\
Taxa aprov. vagas $^{2}$ & 23,3 & 38,6 & 48,9 & 27,0 & 14,0 & 31,4 & 11,6 & 36,4 \\
Taxa admissão $^{3}$ & 4,0 & 4,7 & 7,9 & 4,4 & 2,7 & 4,6 & 1,7 & 34,7 \\
\hline 2014 & Brasil & N & NE & Co & \multicolumn{1}{c}{ SE } & S & Desvio-padrão $^{4}$ & Coeficiente de variação $^{5}$ \\
\hline Taxa efetividade $^{1}$ & 13,0 & 11,3 & 20,8 & 15,6 & 7,0 & 20,6 & 5,4 & 35,5 \\
Taxa aprov.vagas $^{2}$ & 26,0 & 32,7 & 46,1 & 28,5 & 14,0 & 34,8 & 10,4 & 33,3 \\
Taxa admissão $^{3}$ & 3,5 & 4,1 & 9,8 & 4,6 & 1,6 & 4,4 & 2,7 & 54,4 \\
\hline
\end{tabular}

Fonte: MTE/SPPE, 2013 e 2014.

Elaboração dos autores.

Notas: ${ }^{1}$ Razão entre número de trabalhadores colocados e número de trabalhadores inscritos.

${ }^{2}$ Razão entre número de trabalhadores colocados e número de vagas captadas.

${ }^{3}$ Razão entre número de trabalhadores colocados e número de trabalhadores admitidos (segundo o Caged).

${ }^{4}$ Desvio-padrão: calculado a partir das taxas das regiões N, NE, CO, SE e S.

${ }^{5}$ Coeficiente de variação: calculado a partir das médias das taxas das regiões N, NE, CO, SE e S.

Por sua vez, as taxas de aproveitamento contrastam o número de trabalhadores colocados e o número de vagas captadas por esses serviços posicionando-se ao redor de $25 \%$ no período recente (ainda que com um leve aumento entre 2013 e 2014). Em outros termos, no Brasil como um todo, apenas um quarto das vagas captadas pelos serviços de intermediação é aproveitada pelos trabalhadores. 
Mencione-se que todos esses indicadores dos serviços de intermediação variam bastante, conforme a região considerada para a análise, como pode ser visto com clareza no gráfico 7. Historicamente, o Nordeste destaca-se com os melhores indicadores, ao passo que o Sudeste indica os piores.

Alguns fatores que podem explicar isso já foram aventados pela literatura especializada, incluindo: a dimensão do mercado laboral regional, a organizaçáo desse mercado, a segmentação desse mercado, a competição entre agências públicas e privadas e assim por diante (Dieese, 2010; Guimarães, 2004; MTE, 2013; Sabóia e Falvo, 2010; Silva et al., 2013).

\section{GRÁFICO 7}

Indicadores nacionais e regionais da intermediação pública de trabalho, realizada no âmbito do Sine (2013)

(Em números relativos - \%)

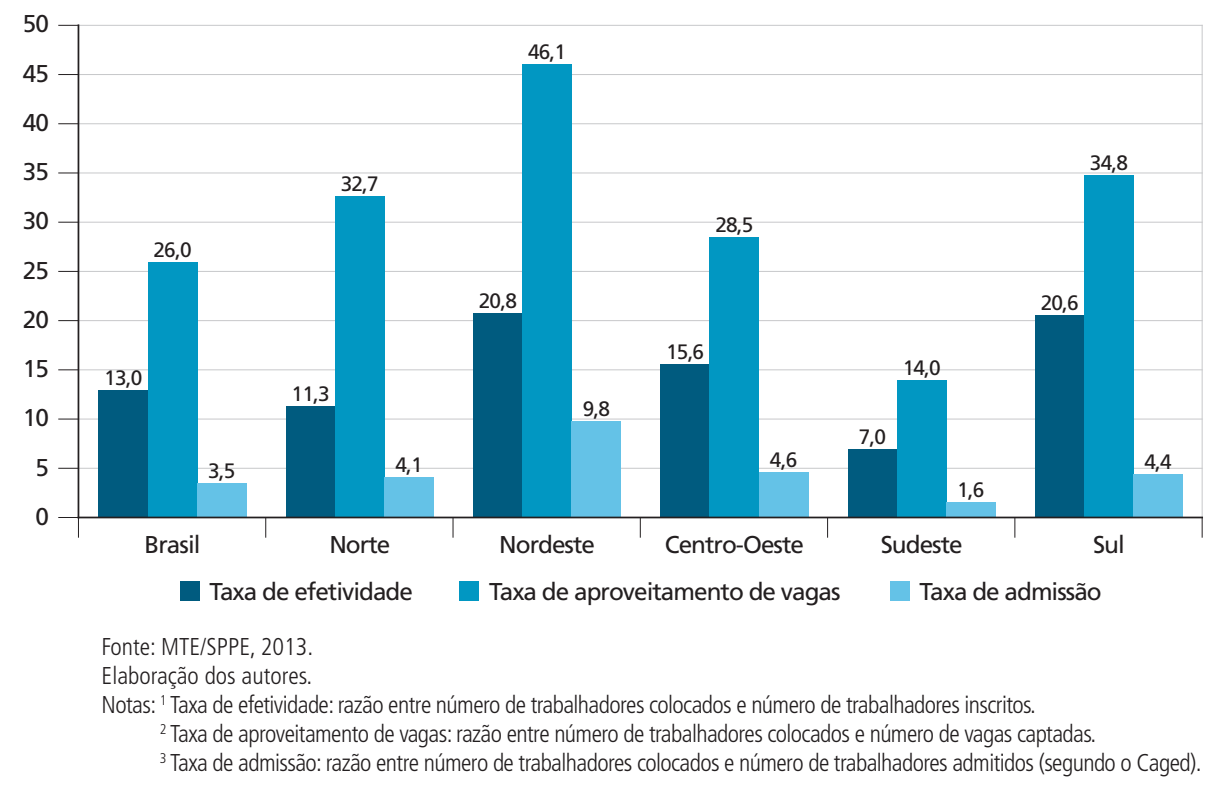

Em que pese essa variabilidade regional, para o Brasil como um conjunto, permanece o questionamento acerca da importância dos serviços de intermediação no mercado de trabalho. E esse questionamento, que já se fazia presente nos anos 2000 quando o ciclo econômico era de alta, provavelmente, ganhará força nos próximos anos, quando o ciclo sinalizado é de acentuada baixa. Ou seja, o que aguarda os serviços de intermediação, agora que se desenha um ciclo de baixa para a economia brasileira? Se no ciclo de alta o desempenho desses serviços já não foi o melhor, o que esperar de agora em diante? 
Como é claro, as respostas para isso estão em aberto. Todavia, provavelmente, as instituiçóes responsáveis pelos serviços (com destaque para o MTE) terão de fortalecer e de aperfeiçoar ainda mais sua atuação, para compensar os problemas adicionais que o ciclo econômico passará a trazer para a intermediação laboral.

Pode-se dizer que essas instituiçóes já vêm fortalecendo e aperfeiçoando tais serviços. Diversas iniciativas destacam-se nesse sentido, como a reorganização da estrutura e do funcionamento do Sine, cujas agências são um ponto de articulação de todas as políticas laborais, sejam elas transferências, sejam elas serviços.

Essa articulação vem sendo reforçada nos anos recentes, de modo que os trabalhadores desempregados (foco comum de todas essas políticas) possam realizar, no mesmo local e ao mesmo tempo, solicitaçóes de transferências e de serviços destacando-se os de intermediação.

Nessa articulação, vem desempenhando papel-chave o sistema informatizado de dados chamado Mais Emprego, implantado desde 2011 pelo MTE. ${ }^{58}$ Esse sistema disponibiliza, para a gestão das transferências e dos serviços, informaçôes atualizadas e unificadas, permitindo uma melhor articulação entre seguro-desemprego, abono salarial, intermediaçáo e qualificação ocupacional.

E outra iniciativa relevante nesse sentido pode vir a ser a implantação do Sistema Único de Trabalho (SUT). ${ }^{59}$ Trata-se de sistema de políticas laborais, nacionalmente articulado, mas também descentralizado, custeado e gerido por todos os entes federados, mas sob a coordenação federal (do MTE) e com a participação de trabalhadores e empresas. A depender de como venha a ser implantado, esse sistema pode carrear mais recursos para o fortalecimento e o aperfeiçoamento dos serviços de intermediação.

\section{TEMA EM DESTAQUE: TERCEIRIZAÇÃO NO BRASIL - ANÁLISE PRELIMINAR DO PROJETO DE LEI № 4.330/2004}

A terceirização pode ter impactos importantes no mercado de trabalho brasileiro, especialmente para os trabalhadores. Por isso, é relevante discutir uma regulação desse fenômeno - em especial, uma regulação legislativa (dado que a jurisprudencial está em questão, como se verá adiante).

O Projeto de Lei no 4.330/2004, aprovado pela Câmara dos Deputados, é apenas uma das propostas em discussão para essa regulação legislativa. No entanto, é a que se encontra mais à frente dentro do processo parlamentar, sendo esta a razão de sua escolha para estudo nesta ediçâao. 
Como será visto, há dúvidas se Projeto de Lei no 4.330/2004 é a melhor opção para uma regulação legislativa da terceirização. Provavelmente, mais avaliaçóes de impacto desse fenômeno deveriam ser realizadas, antes de qualquer decisão do parlamento sobre esse projeto de lei.

\subsection{0 que é terceirização}

Um dos possíveis conceitos de terceirização é o que destaca a disjuntiva entre as dimensões jurídicas e econômicas da relação de trabalho. $\mathrm{O}$ trabalhador labora para uma empresa (chamada de 'contratante'), mas todos os direitos relacionados ao seu trabalho estão ligados a outra - uma empresa intermediária (denominada “contratada") (Barros, 2006; Delgado, 2006).

No Brasil urbano, desde a CLT (Consolidação das Leis do Trabalho de 1943), a regulação da relação mais comum de trabalho (a de assalariamento) não prevê esse tipo de disjuntiva. Os direitos do trabalhador são garantidos pela empresa em que ele realmente trabalha. Em outras palavras, contratante e contratada são a mesma empresa nessa relação, que é denominada bilateral.

No entanto, de acordo com a regulação de uma relação terceirizada, esses direitos não são garantidos pela empresa em que o trabalhador realmente labora, mas por uma empresa intermediária. Desse modo, contratante e contratada são empresas diferentes, estabelecendo uma relação trilateral com o trabalhador.

É importante notar que a terceirização pode ocorrer por meio de trabalho assalariado ou por conta própria. No primeiro caso, o trabalhador continua a ser um assalariado, com todos os atributos desse tipo de relação laboral. ${ }^{60}$ No segundo caso, o trabalhador encontra-se por conta própria, trabalhando mediante uma variedade de mecanismos (cooperativas, empresas individuais e assim por diante) (Barros, 2006; Delgado, 2006).

Em ambos os casos, a terceirização pode ter variados efeitos no mercado laboral brasileiro, alguns dos quais podem se mostrar bastante negativos. Esses impactos são o principal tema deste texto, que apresenta um breve histórico da terceirização no Brasil, a nova proposta de regulação discutida no parlamento, bem como os seus prós e contras.

60. De acordo com a legislação trabalhista brasileira (enraizada principalmente em torno da CLT), um trabalhador é parte de uma relação de trabalho assalariado quando sua relação com a empresa é pessoal, típica, subordinada e remunerada. De acordo com boa parte da jurisprudência e da literatura jurídica, "pessoal" significa que o trabalhador não pode se fazer substituir sem a aceitação prévia da empresa, porque a relação entre eles é intuitu personae. "Típica" (ou "habitual") significa que a atividade do trabalhador integra as atividades normais, regulares, ordinárias da empresa. 'Subordinada' significa que a forma como o trabalhador desenvolve suas atividades é definida pela empresa (e não pelo próprio trabalhador). "Remunerada" significa que o trabalhador desenvolve sua atividade esperando uma contrapartida financeira, monetária (Delgado, 2006). 


\subsection{Terceirização por meio do trabalho assalariado}

Historicamente, a CLT não enfocou qualquer relação trilateral de trabalho, como a que resulta da terceirização. Apesar disso, outras normas surgiram no Brasil desde o final da década de 1960, dedicando atenção a relaçóes trilaterais (Barros, 2006; Delgado, 2006).

Nesse sentido, pode-se mencionar o Decreto no 200/1967 e a Lei no 5.645/1970, que estabeleceram que, sempre que possível, as instituiçóes do governo deveriam adquirir os chamados serviços "instrumentais" (não finalísticos) de empresas privadas. ${ }^{61}$ Exemplos desses serviços, não relacionados com as finalidades dessas instituiçóes, foram os de limpeza de instalaçôes, transporte de pessoal, manutenção de equipamentos, serviços de segurança e assim por diante.

Assim, no início, a terceirização foi "estimulada” pelo Estado no setor público, estritamente para fornecer serviços instrumentais para instituiçóes governamentais. ${ }^{62}$ No entanto, desde meados da década de 1970, o fenômeno disseminou-se bastante, movendo-se do setor público para o privado, o que significou uma grande mudança na sua trajetória.

Com as Leis no 6.019/1974, no 7.102/1983 e no 8.863/1994, as empresas privadas foram autorizadas a adquirir serviços instrumentais de outras empresas no mercado. A primeira lei referiu-se a serviços temporários de qualquer natureza, ao passo que a segunda e a terceira referiram-se especificamente a serviços permanentes de segurança.

Por isso, a partir dos anos 1970, a terceirização foi "fomentada" pelo Estado não só no setor público, mas também no privado. A esse respeito, é importante sublinhar que o ente estatal não se comportou de maneira uniforme, propriamente falando.

De um lado, os poderes Executivo e Legislativo editaram várias normas que "incentivaram" a terceirização (como as já mencionadas). De outro, o Poder Judiciário e o Ministério Público agiram no sentido contrário, limitando as possibilidades para esse fenômeno (Artur, 2007; Biavaschi, 2013; Campos, 2009).

Em 1986, o TST editou a Súmula no 256, que, regulamentando essas possibilidades, estabeleceu que a terceirização somente seria permitida nos casos previstos pelas Leis $\mathrm{n}^{\circ}$ 6.019/1974 e nº 7.102/1983.

61. A definição de serviços finalísticos versus instrumentais sempre foi algo complicado no direito, na jurisprudência e na literatura jurídica. Mesmo documentos oficiais, produzidos pelo Tribunal Superior do Trabalho (TST), enfrentam dificuldades na caracterização desses serviços - a este respeito, verificar (Brasil, 2014). De qualquer forma, uma definição comum e simples é que os serviços finalísticos fazem parte das atividades normais, regulares, comuns e, principalmente, essenciais desenvolvidas pelas empresas, ao passo que os serviços instrumentais não o fazem (Delgado, 2006).

62. As aspas na palavra "estimulada" justificam-se pelo fato de, provavelmente, o Estado brasileiro refletir, com a edição de novas normas sobre a terceirização, posições em conflito nas esferas econômica, social e política - em particular, distintas posições adotadas por representantes dos trabalhadores e dos empresários. 0 mesmo aplica-se a palavras semelhantes, utilizadas na sequência, como "fomentada", "incentivada" e assim por diante. 
Mais tarde, depois de um debate intenso, o mesmo tribunal publicou uma regulação menos estrita. De acordo com a Súmula no 331/1993, a terceirização

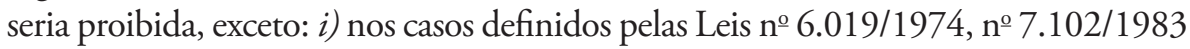
e no 8.863/1994; ii) nos casos de serviços de limpeza e conservação; iii) nos casos de serviços especializados - que deveriam ser apenas instrumentais, realizados sem pessoalidade e subordinação; iv) nos casos de serviços instrumentais adquiridos por instituições governamentais. ${ }^{63}$

Em suma, no que diz respeito à terceirização realizada por meio do trabalho assalariado, o Estado brasileiro não se comportou de forma homogênea nas últimas décadas. Por um lado, os poderes Legislativo e Executivo ampliaram as possibilidades de manifestação desse fenômeno; por outro, o Poder Judiciário e o Ministério Público restringiram-nas.

\subsection{Terceirização mediante trabalho por conta própria}

Como já apontado, além da terceirização por meio do trabalho assalariado, existe uma outra, promovida mediante o trabalho por conta própria. Nesta última, o fenômeno se faz acompanhar de mecanismos como as cooperativas e as empresas individuais.

De acordo com a legislaçẫo brasileira, as cooperativas (de trabalho) são organizações compostas por grupos de pessoas, que laboram em atividades tipicamente coletivas. Essas organizações constituídas por trabalhadores começaram a ser regulamentadas no início da década de 1970, pela Lei no 5.764/1970.

Historicamente, a CLT não se preocupou com as relações de trabalho das cooperativas, porque elas sempre foram concebidas como uma espécie de trabalho por conta própria (ou autônomo). E o foco da CLT, como mencionado antes, sempre esteve sobre as relações de trabalho assalariado (subordinado).

Apesar disso, na metade dos anos 1990, a CLT foi modificada pela Lei $n^{\circ}$ 8.949/1994, que introduziu um dispositivo estabelecendo que, quaisquer que fossem as atividades desenvolvidas, não haveria vínculo de trabalho assalariado entre as cooperativas e seus trabalhadores, bem como entre esses trabalhadores e as empresas que adquirissem serviços de cooperativas.

Com esse novo dispositivo, estabeleceu-se a presunçáo legal de que os trabalhadores cooperativados não realizariam trabalho assalariado, mesmo quando presentes os atributos dessa relação laboral (como a pessoalidade, a habitualidade, a

63. Em qualquer um dos casos da Súmula no 331/1993, há responsabilidade subsidiária do contratante de serviços terceirizados. Em outras palavras, o contratante tem a responsabilidade de arcar com os direitos do trabalhador (ainda que de forma subsidiária), se por acaso o contratado não for capaz de pagar por eles. 
subordinação e a onerosidade). ${ }^{64} \mathrm{E}$ isso fez muita diferença para esses trabalhadores, porque eles tenderam a perder direitos - proteçóes e garantias - instituídos pela CLT.

Além disso, esse novo dispositivo abriu possibilidades para que as empresas pudessem adquirir todos os serviços cooperados no mercado. E náo somente serviços instrumentais, mas também finalísticos, o que representou um problema adicional no debate acerca da terceirização.

Mais além das cooperativas, a terceirização mediante o trabalho por conta própria pode ocorrer com o recurso às empresas individuais. Grosso modo, essas empresas são constituídas por um único trabalhador (pessoa física), que se transforma em uma entidade (pessoa jurídica), para oferecer seus serviços no mercado.

As empresas individuais têm uma extensa história na legislação brasileira, mas elas foram claramente "fomentadas" na década de 2000, pelas Leis no 11.196/2005 e no 11.442/2007. A primeira norma definiu uma regulação específica para o trabalho denominado "intelectual" - de natureza artística, científica e de comunicação. Já a segunda norma definiu uma regulação para o trabalho realizado por motoristas profissionais, nos transportes rodoviários de carga.

Em certa medida, essas leis estabeleceram a presunção legal, de que os trabalhadores transformados em pessoas jurídicas não contavam com os direitos atribuídos pelo direito do trabalho - em especial, pela CLT. Em vez disso, afirmava-se que suas atividades eram regulamentadas por leis civis e comerciais, o que fez muita diferença para esses trabalhadores em termos de direitos - ou, em outras palavras, em termos de proteçóes e garantias.

Além disso, como pessoas jurídicas, esses trabalhadores tornaram-se capazes de fornecer quaisquer serviços a outras empresas, instrumentais ou mesmo finalísticos o que representou, mais uma vez, uma questão polêmica na discussão sobre a terceirização.

Em suma, a respeito de terceirizaçáo efetuada por meio do trabalho por conta própria, pode-se dizer que o Estado brasileiro a incentivou ao longo das décadas de 1990 e 2000, principalmente mediante normas emanadas dos poderes Executivo e Legislativo.

No entanto, mais uma vez, o Poder Judiciário e o Ministério Público seguiram pelo caminho oposto, o que reduziu as possibilidades de expansão da terceirização, especialmente daquela que se dava por meio de cooperativas (Artur, 2007; Biavaschi, 2013; Campos, 2009). Isso pôde ser constatado em numerosas açôes judiciais, em que os tribunais decidiram pela ilegalidade da terceirização mediante cooperativas e, paralelamente, pelo reconhecimento do vínculo assalariado de trabalho.

64. Presunção legal que, em larga medida, segue no sentido contrário de alguns princípios organizadores do direito laboral, como o da "primazia da realidade". A este respeito, ver Barros (2006), Delgado (2006) e Nascimento (2005). 


\subsection{Problemas relacionados à regulação da terceirização}

Como visto, a terceirização tem uma longa história no mercado de trabalho brasileiro, que remonta ao final da década de 1960. Nas décadas de 1990 e 2000, essa história acelerou bastante, com várias iniciativas normativas "promovendo" a terceirização.

De qualquer maneira, é importante perceber que, atualmente, há alguns problemas de segurança jurídica, envolvendo a regulação da terceirização por meio de iniciativas jurisprudenciais, tal como a Súmula no 331/1993 do TST.

Esses problemas podem ser notados, por exemplo, no questionamento dessa súmula, que está ocorrendo por meio de açóes na cúpula do sistema judicial brasileiro o Supremo Tribunal Federal (STF) (Ipea, 2012). Entre os aspectos questionados da Súmula no 331/1993, está a distinção entre os serviços instrumentais e finalísticos - o que é uma questão crucial no debate sobre a terceirização, como já visto.

Até o momento, o STF não demonstrou uma tendência clara de decidir, em tais açôes, contra a possibilidade de terceirização de serviços finalísticos. E, se isso realmente prevalecer no julgamento efetuado por esse tribunal, as empresas serão capazes de adquirir quaisquer tipos de serviços no mercado, não apenas instrumentais.

Como isso pode ter diversos impactos no mercado de trabalho, com destaque para os trabalhadores, pode ser realmente importante debater outro tipo de regulação da terceirização no país. Não uma regulação jurisprudencial, com toda a sua incerteza, mas sim uma legislativa, propriamente falando.

\subsection{Alguns aspectos do Projeto no 4.330/2004}

Atualmente, há diversas propostas em tramitação no parlamento brasileiro, capazes de definir uma regulação legislativa para a terceirização. Em meio a todas elas, a que se encontra mais à frente no processo legislativo é o Projeto de Lei no 4.330/2004 o objeto de interesse deste texto. ${ }^{65}$

Essa proposta é bastante extensa, abrangendo diferentes aspectos da terceirização, o que dificulta a análise de todas as suas regras. Desse modo, o objetivo aqui é apenas abordar as principais regras, bem como verificar em que medida elas podem afetar os trabalhadores ou as empresas (ou mesmo o Estado).

Para começar, o foco do Projeto de Lei no 4.330/2004 é essencialmente a terceirização que ocorre por meio do trabalho assalariado (e não mediante o trabalho por conta própria). Ademais, o seu foco é a terceirização que se dá no setor privado (deixando o setor público fora do seu alcance). ${ }^{66}$ No entanto, é relevante apontar que o projeto inclui em seu bojo as empresas estatais, que são

65. No momento de redação deste artigo, a versão mais recente do Projeto de Lei oㅡ 4.330/2004 estava disponível em: $<$ http://goo.gl/X5mqxB>. Acesso em: jun. 2015.

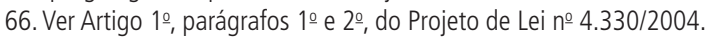


algumas das principais empresas da economia brasileira e que já fazem amplo uso do trabalho terceirizado. ${ }^{67}$

Se as empresas contratantes da terceirização podem ser quaisquer (desde que do setor privado da economia), as contratadas só podem ser aquelas especializadas em um serviço singular, com capacidade econômica e qualificação técnica para a prestação de tal serviço. ${ }^{68}$ Portanto, há alguns requisitos a serem observados para as empresas contratadas poderem participar da terceirização, o que pode restringir a disseminação desse fenômeno.

De todo modo, definidas as empresas que podem participar de terceirização (contratantes e contratadas), bem como o tipo de trabalhadores (basicamente os trabalhadores assalariados), é hora de examinar como as regras do Projeto de Lei no 4.330/2004 podem afetar cada lado da relação de trabalho terceirizado.

No que concerne às empresas, a regra mais importante (no âmbito do 'dever-ser' normativo) é provavelmente aquela que admite explicitamente a possibilidade de terceirização de quaisquer tipos de serviços, instrumentais ou finalísticos. ${ }^{69}$

Isso pode ter impactos substanciais no mercado de trabalho brasileiro, porque as empresas serão capazes de terceirizar muitos outros aspectos do seu processo de produção, muito além daqueles admitidos pela Súmula no 331/1993 do TST.

Essa possibilidade de terceirização de serviços finalísticos é um dos principais temas do debate atualmente realizado - e é o mesmo ponto que foi recentemente questionado em açôes no STF, como já descrito (Ipea, 2012).

Por outro lado, no que respeita aos trabalhadores, há vários dispositivos relevantes no Projeto de Lei no $4.330 / 2004$, a maioria deles (ao menos no âmbito do "dever-ser" normativo) impondo restriçóes à terceirização:

- não é admitido para as empresas despedir trabalhadores e terceirizar parcelas do processo de produção para eles, ${ }^{70}$ pelo menos no período de doze meses após as demissóes; ${ }^{71}$

67. A liderança do atual governo solicitou à liderança do parlamento incluir as empresas estatais (que são pessoas jurídicas de direito privado) no âmbito do Projeto de Lei no 4.330/2004. Para mais detalhes sobre isso, verificar Cunto (2015). Corrobora esta solicitação governamental o pedido da Petrobras, datado de julho de 2015, para integrar a ação judicial em que se discute a terceirização de atividades finalísticas no STF (como Amicus Curiae), para defender essa terceirização (pelo que se depreende do pedido, inclusive em atividades finalísticas). Para mais detalhes sobre isso, verificar Petrobras (2015). Por fim, algumas informações atualizadas sobre o peso da terceirização junto às empresas estatais (em particular, junto à Petrobras) podem ser encontradas em Druck (2015) e Pastore e Ueki (2015).

68. Ver Artigo 2ㅜ, inciso III, do Projeto de Lei no 4.330/2004.

69. Ver Artigo 4ㄴ, caput, do Projeto de Lei ํㅜ 4.330/2004.

70. Supondo que os trabalhadores demitidos se transformaram em pessoas jurídicas (cooperativas, empresas individuais e assim por diante).

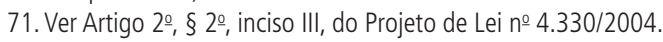


- trabalhadores terceirizados só podem ser subordinados às empresas contratadas, ${ }^{72}$ e não às contratantes. ${ }^{73}$ E os trabalhadores só podem desenvolver as atividades especificamente previstas no contrato de terceirização; ${ }^{74}$

- além disso, a chamada 'subterceirização' não é permitida ${ }^{75}$, exceto em situaçóes específicas, previamente estabelecidas em contrato, comunicadas aos sindicatos de trabalhadores etc; ${ }^{76}$

- as empresas contratadas têm de oferecer, antecipadamente, garantias financeiras de que vão cumprir com as obrigaçóes relacionadas ao trabalho, à previdência social e aos tributos; ${ }^{77}$

- as empresas contratantes têm que monitorar continuamente a conformidade das contratadas com essas mesmas obrigaçóes (trabalhistas, previdenciárias e tributárias) $;^{78}$

- as empresas contratantes têm responsabilidade solidária quanto às obrigaçóes trabalhistas e previdenciárias das contratadas, mesmo nos casos de subterceirização; ${ }^{79}$

- as empresas contratantes têm de informar os sindicatos de trabalhadores sobre qualquer tipo de terceirizaçáo realizada (depois ou mesmo antes da sua realização); ${ }^{80}$

- as empresas contratantes têm que garantir, para os trabalhadores terceirizados, as mesmas condiçóes de trabalho - em relação a: alimentação, transporte, formação, segurança e serviços de saúde no trabalho; ${ }^{81}$

- quando as empresas contratantes e contratadas forem parte de uma mesma categoria econômica, ${ }^{82}$ os trabalhadores dessas segundas seráo representados pelo mesmo sindicato de trabalhadores das primeiras. ${ }^{83}$

72. "Subordinados" significa, neste caso, serem contratados, controlados e remunerados.

73. Ver Artigo 3, § 1, do Projeto de Lei no 4.330/2004.

74. Ver Artigo 11, do Projeto de Lei no $0.330 / 2004$.

75. Trata-se da situação em que as empresas contratadas repassam, a outras empresas, parcelas dos serviços que lhes foram demandados pelas contratantes.

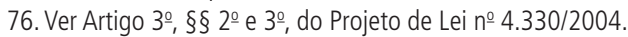

77. Ver Artigo 5o, inciso III, bem como o Artigo 5, § 2으, do Projeto de Lei no 4.330/2004.

78. Ver Artigo 5o, incisos IV, V e VI, bem como o Artigo 16, do Projeto de Lei no 4.330/2004.

79. Ver Artigo 15, caput e Parágrafo Único, do Projeto de Lei no 4.330/2004. A discussão envolvendo os dois tipos de responsabilidade em situação de terceirização laboral (responsabilidade solidária versus subsidiária) é ampla e antiga. Para mais detalhes sobre isso, verificar Delgado (2006).

80. Ver artigo 70 do Projeto de Lei no 4.330/2004.

81. Ver artigo 12, incisos I, II e Parágrafo Único, bem como Artigo 13, do Projeto de Lei no 4.330/2004.

82. De acordo com a CLT, a sindicalização dos trabalhadores no Brasil deve obedecer a definições econômicas e profissionais. Normalmente, um sindicato pode representar apenas os trabalhadores de uma categoria econômica particular (definida pelo tipo de atividade de sua empresa) e de uma categoria profissional específica (definida pelo tipo de trabalho desenvolvido pelos próprios trabalhadores) (Delgado, 2006).

83. Ver Artigo 8o do Projeto de Lei ํㅜ 4.330/2004. 
Em suma, do ponto de vista dos trabalhadores, essas são as principais regras do Projeto de Lei $\mathrm{n}^{\circ} 4.330 / 2004$. E a maioria delas tende a restringir as possibilidades de terceirização, por uma variedade de meios - especialmente, mediante a imposição de controles sobre as empresas contratadas, bem como por meio da imposição de responsabilidades para empresas contratadas e contratantes.

É importante acrescentar que, em qualquer situação, o Projeto de Lei no 4.330/2004 prevê que, caso a relação de trabalho apresente os atributos de uma relação assalariada ordinária entre trabalhadores terceirizados e empresas contratantes (como a pessoalidade, a habitualidade, a subordinação e a onerosidade), a relação direta entre esses trabalhadores e essas empresas será declarada por qualquer autoridade (como os tribunais de trabalho). ${ }^{84}$

\section{CONSIDERAÇÕES FINAIS}

Como afirmado anteriormente, atualmente, no parlamento brasileiro, há várias propostas para instituir uma regulação legislativa para a terceirização. O Projeto de Lei no 4.330/2004 é apenas uma dessas propostas - provavelmente, a que se encontra mais à frente no processo legislativo.

É esta a melhor opção para regular a terceirização? Há um debate intenso sobre isso, envolvendo principalmente os representantes dos trabalhadores e das empresas. Especificamente do ponto de vista dos trabalhadores, existem diversos aspectos que podem causar muita apreensão.

Em primeiro lugar, há preocupaçôes sobre os direitos dos trabalhadores. Seguindo por meio da rede de empresas envolvidas na terceirização, é comum passar de uma grande empresa para outra pequena, de uma empresa bem estruturada para outra menos organizada. Esse simples fato coloca desafios para os direitos dos trabalhadores, pois estes tendem a ser mais extensos e mais fortes em empresas grandes e/ou bem estruturadas (Cardoso e Lage, 2007; Dieese, 2007).

Além disso, seguindo pela cadeia de empresas enredadas na terceirização, via de regra, torna-se mais difícil sindicalizar e mobilizar os trabalhadores. Esse fato coloca desafios adicionais para os direitos dos trabalhadores - especificamente, para aqueles que advêm da negociação coletiva. Tornando-se mais difícil atrair trabalhadores para os sindicatos, bem como mobilizá-los para negociar, esses direitos ficam mais propensos a se retraírem e a se enfraquecerem (Dieese, 2007; Dieese, 2012; Marcelino, 2008).

Em segundo lugar, há preocupações sobre as garantias dos trabalhadores. Como mencionado, seguindo pela rede de empresas envolvidas com a terceirização,

84. Exceto para os casos de empresas estatais, porque a Constituição Brasileira determina que essas empresas só podem ter seus trabalhadores contratados por meio de concursos públicos (Delgado, 2006). 
geralmente passa-se de uma grande empresa para outra pequena, de uma empresa bem-estruturada para outra menos organizada. E esse fato tem implicaçóes em termos de garantias trabalhistas, porque empresas pequenas e/ou precárias enfrentam mais dificuldades para oferecer garantias para os direitos dos trabalhadores (Cardoso e Lage, de 2007; Dieese, 2007).

Em poucas palavras, devido à lista de ameaças descritas, a terceirização naturalmente provoca apreensão entre os trabalhadores. Alguns dos aspectos mencionados sobre Projeto de Lei no 4.330/2004 podem talvez amenizar essa preocupação - como aqueles que impóem controles sobre as empresas contratadas, bem como aqueles que impóem responsabilidades para as empresas contratadas e contratantes.

No entanto, talvez seja cedo demais para saber, com antecedência, se outros aspectos do Projeto de Lei no 4.330/2004 não provocariam ainda mais preocupação em meio aos trabalhadores - como, por exemplo, aquele que permite a terceirização em quaisquer tipos de serviços, instrumentais ou finalísticos.

Provavelmente, estudos adicionais deveriam ser realizados sobre os possíveis impactos da terceirização, antes de qualquer deliberação final do parlamento brasileiro sobre o tema. Afinal de contas, a terceirização pode trazer muitos impactos relevantes para o mercado de trabalho do país, especialmente para os trabalhadores.

QUADRO 1

Problemas nos estudos empíricos sobre a terceirização

Na última década, poucas avaliações de impacto sobre a terceirização foram realizadas no Brasil. E as poucas efetuadas apresentaram uma variedade de problemas. Entre outros, é possível mencionar os seguintes: i) dados insuficientes (especialmente no que se refere a dados quantitativos); ii) estimativas indiretas de trabalhadores terceirizados (não há estimativas diretas); iii) múltiplos vieses de análise (de seleção e de comparação).

Infelizmente, todos esses problemas metodológicos afetaram a qualidade das avaliações produzidas sobre a terceirização - como é possível verificar em Dieese/CUT (2011), por exemplo. E, sem avaliações qualificadas, é difícil manter aberto o debate sobre a terceirização no Brasil. É por isso que novos estudos deveriam ser realizados, antes de qualquer deliberação legislativa sobre o Projeto de Lei no 4.330/2004.

\section{REFERÊNCIAS}

ALMEIDA, M. Precisamos de um modelo econômico brasileiro? Desenvolvimento local, política econômica e crescimento, 18 nov. 2013. Disponível em: <https:// goo.gl/o0vo6m>. Acesso em: 14 jul. 2015.

. A nova matriz econômica falhou. Desenvolvimento Local, Política Econômica e Crescimento, 4 maio 2014. Disponível em: <https://goo.gl/xy0Vmm>. Acesso em: 14 jul. 2015. 
ALMEIDA, M.; LISBOA, M. B.; PESSOA, S. O ajuste inevitável: ou o país que ficou velho antes de se tornar desenvolvido, jul. 2015. Disponível em: <https://goo.gl/xy0Vmm>. Acesso em: 22 jul. 2015.

AMORIM, B. et al. Fundo de Amparo ao Trabalhador: uma solução de financiamento esgotada? In: Brasil em desenvolvimento 2011: Estado, planejamento e políticas públicas. 1. Ed. Brasília: Ipea, 2012. V. 2, p. 241-283.

ASSOCIAÇÃONACIONALDOSMAGISTRADOSDAJUSTIÇADOTRABALHO_ ANAMATRA. Nota Pública da Anamatra sobre o Programa de Proteçáo ao Emprego. 2015. Disponível em: <http://goo.gl/sr5DSz>. Acesso em: 27 jul. 2015.

AZEREDO, B. Políticas públicas de emprego: a experiência brasileira. 1. Ed. São Paulo: Abet, 1998.

ARTUR, K. O TST frente à terceirização. São Carlos: UFSCar, 2007.

BARBOSA, N. Modelo de desenvolvimento do Brasil: oportunidades e desafios. In: SEMINÁRIO A CRISE NO CAPITALISMO E O DESENVOLVIMENTO DO BRASIL, Rio de Janeiro, 28 nov. 2011. Disponível em: <http://goo.gl/ftWg3M>. Acesso em: 22 jul. 2015

BARROS, A. M. Curso de direito do trabalho. São Paulo: LTr Editora, 2006.

BARBOSA, A. F.; MORETTO, A. J. Políticas de emprego e proteçáo social. 1. Ed. São Paulo: Abet, 1998.

BARBOSA, N.; SOUZA, J. A. A inflexão do governo Lula: política econômica, crescimento e distribuição de renda. In: Brasil: entre o passado e o futuro. 1. Ed. São Paulo: Boitempo, 2010, p. 200.

BARROS, J. R. M. DE. Lento, seguro e gradual. O Estado de Sáo Paulo, 22 jan. 2014 a. . Política macro e competitividade. O Estado de Sáo Paulo, 27 jun. 2014b.

BELlUZZO, L. G. Os poderes nos ministérios. Carta Capital, 1ํ dez. 2014.

. Dickens e as metas de inflação. Carta Capital, 1ํ jul. 2015.

BIAVASCHI, M. O capitalismo contemporâneo e as novas formas de contratação da força de trabalho: a terceirização. In: KREIN, J. D. Et al. (Orgs.). Regulaçáo do trabalho e instituiçóes públicas. São Paulo: Perseu Abramo, 2013, p.141-166.

BRASIL. Banco Central do Brasil. Focus: relatório de mercado. Brasília: BCB, 4 dez. 2015. Disponível em: <http://goo.gl/Hpc2ME>. Acesso em: 17 ago. 2016.

. Lei no 8.287/1991, de 20 de dezembro de 1991. Estabelece e consolida critérios para a concessão do Seguro-Desemprego aos pescadores artesanais durante 
os períodos de defeso, instituído pela Lei no 10.779 , de 25 de novembro de 2003, e dá outras providências. Disponível em: <goo.gl/1VvNZt>. Acesso em: 17 ago. 2016.

. Lei no $10.779 / 2003$, de 25 de novembro de 2003.

. Lei no 11.959/2009, de 29 de junho de 2009.

. Ministério do Trabalho e Emprego. Conselho Deliberativo do Fundo de Amparo ao Trabalhador. Resoluçáo Codefat no 468/2005, de 21 de dezembro de 2005. Disponível em: <goo.gl/1VvNZt>. Acesso em:

Resoluçáo Codefat no 657/2010, de 16 de dezembro de 2010. Disponível em: <goo.gl/5n3kle>. Acesso em:

. Ministério do Trabalho e Emprego. Sistema Seguro Desemprego. Instrução Normativa no 1/2011, de 27 de dezembro de 2011 .

. Tribunal Superior do Trabalho. Ofício TST.GP no 1.228/2014. Brasília: TST, 30 dez. 2014. Disponível em: < goo.gl/KOikgO>. Acesso em: 17 jun. 2015. CAMPOS, A. Novos aspectos da regulaçáo do trabalho no Brasil: qual o papel do Estado? Brasília: Ipea, 2009.

CAMPOS, A. G.; CHAVES, J. V. Seguro-defeso: diagnóstico dos problemas enfrentados pelo programa. Ipea, 2014. Disponível em: <http://goo.gl/ZTEcIP>. Acesso em: 23 fev. 2015.

CARDOSO JR., J. C.; GONZALEZ, R. Dilemas e alternativas ao financiamento das políticas públicas de trabalho e renda no Brasil. Econômica, v. 9, n. 2, p. 239-269, dez. 2007.

CARDOSO JR., J. C. et al. Políticas de emprego, trabalho e renda no Brasil: desafios à montagem de um sistema público, integrado e participativo. Ipea, 2006. Disponível em: <http://goo.gl/27FVGj>. Acesso em: 19 ago. 2014.

CARDOSO, A.; LAGE, T. As normas e os fatos: desenho e efetividade das instituiçóes de regulação do mercado de trabalho no Brasil. Rio de Janeiro: FGV, 2007.

CANUTO, O.; SCHELLEKENS, P. Three perspectives on Brazilian growth pessimism. World Bank, 2014. Disponível em: <http://goo.gl/mXNkSw>. Acesso em: 14 jul. 2015.

COSTA, J.; BARBOSA, A.L.; HIRATA, G. Efeitos da ampliaçâo dos direitos trabalhistas sobre a formalizaçáo, jornada de trabalho e salários das empregadas domésticas. ENCONTRO NACIONAL DE ECONOMIA, 43., 2015, Florianópolis, Santa Catarina. Anais... Florianópolis: Anpec, 2015.

CUNTO, R. Dilma mobiliza aliados para reincluir estatais na terceirização. Valor Econômico, 28 abr. 2015. 
CUT - CENTRAL ÚNICA DOS TRABALHADORES; DIEESE DEPARTAMENTO INTERSINDICAL DE ESTATÍSTICA E ESTUDOS SOCIOECONÔMICOS. Terceirizaçáo e desenvolvimento: uma conta que não fecha. São Paulo: CUT/Dieese, 2011.

DEDECCA, C. S. Plano de Proteção ao Emprego: uma iniciativa importante e atabalhoada. O Estado de Sáo Paulo, p. B2, 10 jul. 2015.

DELGADO, M. Curso de direito do trabalho. São Paulo: LTr Editora, 2006.

DIEESE - DEPARTAMENTO INTERSINDICAL DE ESTATÍSTICA E ESTUDOS SOCIOECONÔMICOS. O Processo de terceirizaçáo e seus efeitos sobre os trabalhadores no Brasil. Brasília: Dieese, 2007.

. Terceirizaçáo e negociaçáo coletiva: velhos e novos desafios para o movimento sindical brasileiro. São Paulo: Dieese, 2012.

Intermediação de mão de obra. Dieese, 2010. Disponível em: <http:// goo.gl/wpMlum>. Acesso em: 26 ago. 2014

O programa do Seguro-desemprego: desafios para um permanente aperfeiçoamento. Dieese, 2011. Disponível em: <http://goo.gl/lbmrJl>. Acesso em: 19 set. 2014

DRUCK, G. A terceirização no setor público e a proposta de liberalização da terceirizaçáo pelo PL 4330. São Paulo: Blog da Boitempo, 2015. Disponível em: <http://goo.gl/UYqTal>. Acesso em: 17 ago. 2016.

FRAGA, A. De empregada a diarista: as novas configuraçóes do trabalho doméstico remunerado. Dissertação (Mestrado) - Programa de Pós-Graduação em Sociologia e Antropologia, Instituto de Filosofia e Ciências Sociais, Universidade Federal do Rio de Janeiro. Rio de Janeiro, 2010.

GUIMARÁES, N. O sistema de intermediaçáo de empregos: um outro olhar sobre o mercado de trabalho em São Paulo. Cebrap, 2004. Disponível em: <http://goo.gl/cisJBq> . Acesso em: 26 ago. 2014.

IPEA - INSTITUTO DE PESQUISA ECONÔMICA APLICADA. Mercado de Trabalho: conjuntura e análise. In: Análise do mercado de trabalho. Brasília: Ipea, v. 21, n. 58, p. 9-16, abr. 2015.

. Políticas sociais: acompanhamento e análise. In: Previdência social. Brasília, Ipea, n. 22, p. 19-46, 2014.

. Políticas sociais: acompanhamento e análise. In: Intermediaçáo de mão de obra. Brasília: Ipea, n. 23, p. 339-343, $2014 a$.

Políticas sociais: acompanhamento e análise. In: Sistema único de trabalho. Brasília: Ipea, n. 23, p. 324-328, 2014 b. 
. Políticas sociais: acompanhamento e análise. In: Trabalho e renda: terceirização. Brasília: Ipea, n. 20, 2012, p. 207-210.

IBGE - INSTITUTO BRASILEIRO DE GEOGRAFIA E ESTATÍSTICA. Pesquisa nacional por amostra de domicílios contínua - divulgação mensal. IBGE, 2015. Disponível em: <http://goo.gl/5MvhMQ>. Acesso em: 27 jul. 2015. MANTEGA, G. O primeiro ano da nova matriz econômica. Valor Econômico, 19 dez. 2012.

MARCELINO, P. Terceirizaçáo e açáo sindical: a singularidade da reestruturação do capital no Brasil. Tese (Doutorado em Ciências Sociais), Instituto de Filosofia e Ciências Humanas, Universidade de Campinas, Campinas, 2008.

MARINHO, D.; BALESTRO, M.; WALTER, M. I. (Eds.). Políticas públicas de emprego no Brasil: avaliação externa do seguro-desemprego. 1. ed. Brasília: UnB/FAT/MTE, 2010. v. 1.

MORETTO, A. J. O sistema público de emprego no Brasil: uma construção inacabada. Campinas: Unicamp/Instituto de Economia, 2007.

MTE - MINISTÉRIO DO TRABALHO E EMPREGO. CAGED - CADASTRO GERAL DE EMPREGADOS E DESEMPREGADOS. Síntese do comportamento do mercado de trabalho formal - Brasil - Balanço do ano de 2015. Brasília: MTE, 2016.

. Estudo sobre a Rotatividade de Máo de Obra. Brasília: MTE, 2011. Disponível em: <http://goo.gl/IowkVY>. Acesso em: 28 jul. 2015.

O funcionamento do Sine como política pública de intermediaçáo de mão de obra. Brasília: MTE, 2013. Disponível em: <http://goo.gl/3Q1vYC>. Acesso em: 26 ago. 2014.

NASCIMENTO, A. M. Curso de direito do trabalho. São Paulo: Saraiva, 2005.

PASTORE, J. K. O emprego durante as crises. O Estado de Sáo Paulo, p. B2, 6 nov. 2012a.

. Emprego: é hora de agir. O Estado de Sáo Paulo, p. B2, 4 dez. 2012b. . Com a recessão em curso, a medida é mais do que indicada. O Estado de São Paulo, p. B2, 8 jul. 2015.

PASTORE, J.; UEKI, S. A proibição da terceirização na Petrobras. O Estado de Sáo Paulo, 5 mai. 2015. Disponível em: <http://goo.gl/vmV1ew>. Acesso em: 17 ago. 2016.

PERRY, G. E. et al. Informality: exit and exclusion. Washington, World Bank, 2007. 
. Rescaldo da nova matriz econômica. Folha de Sáo Paulo, 7 jun. 2015.

PETROBRAS. Pedido de ingresso nos autos como amicus curiae: autos do Agravo de Recurso Extraordinário no 713211. Brasília: Petrobras, 2015. Disponível em: <http://goo.gl/5tUfva>. Acesso em: 17 ago. 2016.

PINHEIRO, L.; GONZALEZ, R.; FONTOURA, N. Expansão dos direitos das trabalhadoras domésticas no Brasil. Ipea: Brasília, agosto, 2012. (Nota Técnica n. 10).

. Rescaldo da nova matriz econômica. Folha de Sáo Paulo, 7 jun. 2015.

ROMERO, C. A conta chegou. Valor Econômico, 12 jun. 2013. Disponível em: $<$ goo.gl/8KlJlm>. Acesso em: 14 jul. 2015

. Política econômica: três escolhas possíveis. Valor Econômico, 19 fev. 2014. Disponível em: <goo.gl/zZzrkV>. Acesso em: 2 jul. 2015.

SABÓIA, J.; FALVO, J. F. O papel do Sine na intermediação de mão de obra no Brasil: Nordeste e Sudeste. In: Economia, Desenvolvimento regional e mercado de trabalho do Brasil. 1. ed. Fortaleza: IDT/BNB/Cesit, 2010, p. 364.

SAITO, K.; SOUZA, A. A mobilidade ocupacional das trabalhadoras domésticas no Brasil. XXXVI ENCONTRO NACIONAL DE ECONOMIA - ANPEC, Salvador, Bahia. Anais... Salvador: Anpec, 2008

SILVA, C. A. T. et al. Estudo de custos do sistema nacional de emprego. Brasília: SINEMTE/UnB, 2013. Disponível em: <http://goo.gl/M9B7qA>. Acesso em: 27 ago. 2014.

TAVARES, M. C. et al. Democracia e desenvolvimento para todos: em defesa do futuro do Brasil. 13 out. 2014a. Disponível em: <http://goo.gl/wHgdtn>. Acesso em: 14 jul. 2015.

. Economistas pelo desenvolvimento e pela inclusáo social. 6 nov. 2014 b. Disponível em: <http://goo.gl/8M7HOf>. Acesso em: 14 jul. 2015.

THEODORO, M.I.; SCORZAFAVE, L.G. Impacto da redução dos encargos trabalhistas sobre a formalização das empregadas domésticas. Revista Brasileira de Economia, v. 65, n.1, p. 93-109, jan-mar, 2011.

VILLAVERDE, J. Setores da CUT e da Força Sindical criticam o Plano de Proteção ao Emprego. O Estado de Sáo Paulo, 9 jul. 2015. Disponível em: <goo.gl/VztdDc>. Acesso em: 28 jul. 2015.

UBIDE, Á. O resgate do Brasil. El País, 4 abr. 2015. Disponível em: <goo.gl/gkMc10>. Acesso em: 14 jul. 2015.

ZYLBERSTAJN, H. Para alguns ou para todos? O Estado de Sáo Paulo, p. B2, 8 jul. 2015. 
BIBLIOGRAFIA COMPLEMENTAR

CAETANO, A-R. M. et al. Os reflexos das medidas provisórias 664 e 665 sobre as pensóes, $\mathrm{o}$ abono salarial e o seguro-desemprego em suas modalidades defeso e formal. Brasília: Ipea, 2015 (Texto para Discussão, n. 2067).

CAMPELLO, T.; NÉRI, M. C. Programa Bolsa Família: uma década de inclusão e cidadania. Brasília: Ipea, 2013.

CUT - CENTRAL ÚNICA DOS TRABALHADORES. Terceirização e desenvolvimento: uma conta que não fecha - Dossiê acerca do impacto da terceirização sobre os trabalhadores e propostas para garantir a igualdade de direitos. São Paulo: CUT, 2014.

DAU, D.; RODRIGUES, I.; CONCEIÇÃO, J. (Orgs.). Terceirizaçâo no Brasil: do discurso da inovação à precarização do trabalho. Atualização do debate e perspectivas. São Paulo: Annablume/CUT, 2009.

FIESP - FEDERAÇÃO DAS INDÚSTRIAS DO ESTADO DE SÃO PAULO; CIESP - CENTRO DAS INDÚSTRIAS DO ESTADO DE SÃO PAULO. Terceirizaçáo: nota técnica. São Paulo: Fiesp/Ciesp, 2015.

IMF - WORLD ECONOMIC OUTLOOK UPDATE. Washington, D.C., 2015. Disponível em: <http://goo.gl/ApbLG6>. Acesso em: 10 jul. 2015

PESSOA, S. Downgrade: a culpa é do Estado de Bem-Estar ou da nova matriz? Revista Conjuntura Econômica, v. 68, n. 4, p. 10-11, abr. 2014.

ROMERO, C. Transição para nova política econômica afetou PIB, diz Holland. Valor Econômico, 17 dez. 2012. 


\section{ANEXO - RESUMO DAS REGRAS ESTABELECIDAS PELA LEI № 13.134/2015}

\section{QUADRO A.1}

Alterações na Lei no 7.998/1990 - Seguro-desemprego

\begin{tabular}{|c|c|}
\hline Como era antes & Como é agora \\
\hline $\begin{array}{l}\text { Em caráter excepcional e pelo prazo de seis meses, } \\
\text { os trabalhadores que estejam em situação de } \\
\text { desemprego involuntário pelo período compreen- } \\
\text { dido entre doze e dezoito meses, ininterruptos, e } \\
\text { que já tenham sido beneficiados com o recebimento } \\
\text { do Seguro-desemprego, farão jus a três parcelas do } \\
\text { benefício, correspondente cada uma a R\$ 100,00 } \\
\text { (cem reais). O período de doze a dezoito meses } \\
\text { de que trata o caput será contado a partir do } \\
\text { recebimento da primeira parcela do Seguro-desem- } \\
\text { prego. O benefício poderá estar integrado a ações } \\
\text { de qualificação profissional e articulado com ações } \\
\text { de emprego a serem executadas nas localidades } \\
\text { de domicílio do beneficiado. Caberá ao Conselho } \\
\text { Deliberativo do Fundo de Amparo ao Trabalha- } \\
\text { dor - (Codefat) o estabelecimento, mediante } \\
\text { resolução, das demais condições indispensáveis ao } \\
\text { recebimento do benefício de que trata este artigo, } \\
\text { inclusive quanto à idade e domicílio do empregador } \\
\text { ao qual o trabalhador estava vinculado, bem como } \\
\text { os respectivos limites de comprometimento dos } \\
\text { recursos do FAT. }\end{array}$ & Inexistente. \\
\hline $\begin{array}{l}\text { Terá direito à percepção do seguro-desemprego o } \\
\text { trabalhador dispensado sem justa causa que com- } \\
\text { prove: I - ter recebido salários de pessoa jurídica ou } \\
\text { pessoa física a ela equiparada, relativos a cada um } \\
\text { dos } 6 \text { (seis) meses imediatamente anteriores à data } \\
\text { da dispensa. }\end{array}$ & $\begin{array}{l}\text { Terá direito à percepção do seguro-desemprego o trabalhador dispensado } \\
\text { sem justa causa que comprove: I - ter recebido salários de pessoa jurídica } \\
\text { ou de pessoa física a ela equiparada, relativos a: a) pelo menos } 12 \text { (doze) } \\
\text { meses nos últimos } 18 \text { (dezoito) meses imediatamente anteriores à data de } \\
\text { dispensa, quando da primeira solicitação; b) pelo menos } 9 \text { (nove) meses } \\
\text { nos últimos } 12 \text { (doze) meses imediatamente anteriores à data de dispensa, } \\
\text { quando da segunda solicitação; c) cada um dos } 6 \text { (seis) meses imediata- } \\
\text { mente anteriores à data de dispensa, quando das demais solicitações. }\end{array}$ \\
\hline $\begin{array}{l}\text { Terá direito à percepção do seguro-desemprego o } \\
\text { trabalhador dispensado sem justa causa que com- } \\
\text { prove: II - ter sido empregado de pessoa jurídica } \\
\text { ou pessoa física a ela equiparada ou ter exercido } \\
\text { atividade legalmente reconhecida como autônoma, } \\
\text { durante pelo menos } 15 \text { (quinze) meses nos últimos } \\
24 \text { (vinte e quatro) meses. }\end{array}$ & Inexistente. \\
\hline Inexistente. & $\begin{array}{l}\text { Terá direito à percepção do seguro-desemprego o trabalhador dispensado } \\
\text { sem justa causa que comprove: VI - matrícula e frequência, quando } \\
\text { aplicável, nos termos do regulamento, em curso de formação inicial e } \\
\text { continuada ou de qualificação profissional habilitado pelo Ministério da } \\
\text { Educação, nos termos do art. } 18 \text { da Lei no } 12.513 \text {, de } 26 \text { de outubro de } \\
2011 \text {, ofertado por meio da Bolsa-Formação Trabalhador concedida no } \\
\text { âmbito do Programa Nacional de Acesso ao Ensino Técnico e Emprego } \\
\text { (Pronatec), instituído pela Lei no } 12.513 \text {, de } 26 \text { de outubro de } 2011 \text {, ou de } \\
\text { vagas gratuitas na rede de educação profissional e tecnológica. }\end{array}$ \\
\hline
\end{tabular}


(Continuação)

\begin{tabular}{|c|c|}
\hline Como era antes & Como é agora \\
\hline $\begin{array}{l}\text { O benefício do seguro-desemprego será concedido } \\
\text { ao trabalhador desempregado por um período } \\
\text { máximo variável de três a cinco meses, de forma } \\
\text { contínua ou alternada, a cada período aquisitivo, } \\
\text { cuja duração será definida pelo Codefat. 1o 0 } \\
\text { benefício poderá ser retomado a cada novo período } \\
\text { aquisitivo, observado o disposto no artigo anterior. } \\
\text { 2A determinação do período máximo mencionado } \\
\text { no caput deste artigo observará a seguinte relação } \\
\text { entre o número de parcelas mensais do benefício do } \\
\text { seguro-desemprego e o tempo de serviço do traba- } \\
\text { lhador nos trinta e seis meses que antecederam a } \\
\text { data de dispensa que deu origem ao requerimento } \\
\text { do seguro-desemprego: I - três parcelas, se o } \\
\text { trabalhador comprovar vínculo empregatício com } \\
\text { pessoa jurídica ou pessoa física a ela equiparada, } \\
\text { de no mínimo seis meses e no máximo onze meses, } \\
\text { no período de referência; II - quatro parcelas, se o } \\
\text { trabalhador comprovar vínculo empregatício com } \\
\text { pessoa jurídica ou pessoa física a ela equiparada, } \\
\text { de no mínimo doze meses e no máximo vinte e três } \\
\text { meses, no período de referência; III - cinco parcelas, } \\
\text { se o trabalhador comprovar vínculo emprega- } \\
\text { tício com pessoa jurídica ou pessoa física a ela } \\
\text { equiparada, de no mínimo vinte e quatro meses, no } \\
\text { período de referência. }\end{array}$ & 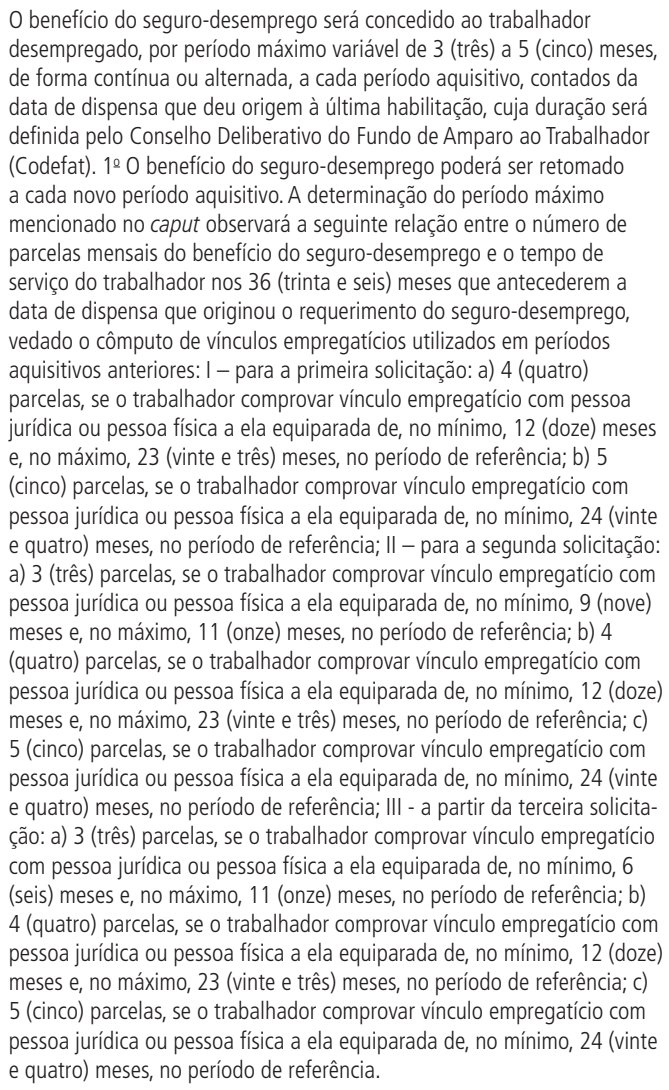 \\
\hline Inexistente. & $\begin{array}{l}\text { O Codefat observará as estatísticas do mercado de trabalho, inclusive o } \\
\text { tempo médio de permanência no emprego, por setor, e recomendará ao } \\
\text { Ministro de Estado do Trabalho e Emprego a adoção de políticas públicas } \\
\text { que julgar adequadas à mitigação da alta rotatividade no emprego. }\end{array}$ \\
\hline Inexistente. & $\begin{array}{l}\text { O pagamento do benefício do seguro-desemprego será suspenso nas } \\
\text { seguintes situações: IV - recusa injustificada por parte do trabalhador } \\
\text { desempregado em participar de ações de recolocação de emprego, } \\
\text { conforme regulamentação do Codefat. }\end{array}$ \\
\hline
\end{tabular}

Elaboração dos autores, com base na Lei no 13.134/2015. 
QUADRO A.2

Alterações na Lei no 10.779/2003 - Seguro-defeso

\begin{tabular}{|c|c|}
\hline Como era antes & Como é agora \\
\hline $\begin{array}{l}0 \text { pescador profissional que exerça sua atividade de forma } \\
\text { artesanal, individualmente ou em regime de economia familiar, } \\
\text { ainda que com o auxílio eventual de parceiros, fará jus ao } \\
\text { benefício de seguro-desemprego, no valor de um salário- } \\
\text {-mínimo mensal, durante o período de defeso de atividade } \\
\text { pesqueira para a preservação da espécie. }\end{array}$ & $\begin{array}{l}\text { O pescador artesanal de que tratam a alínea "b" do inciso } \\
\text { VII do art. } 12 \text { da Lei no } 8.212 \text {, de } 24 \text { de julho de 1991, e a } \\
\text { alínea "b" do inciso VII do art. } 11 \text { da Lei no } 8.213 \text {, de } 24 \text { de } \\
\text { julho de } 1991 \text {, desde que exerça sua atividade profissional } \\
\text { ininterruptamente, de forma artesanal e individualmente ou } \\
\text { em regime de economia familiar, fará jus ao benefício do } \\
\text { seguro-desemprego, no valor de } 1 \text { (um) salário-mínimo mensal, } \\
\text { durante o período de defeso de atividade pesqueira para a } \\
\text { preservação da espécie. }\end{array}$ \\
\hline $\begin{array}{l}\text { Entende-se como regime de economia familiar o trabalho } \\
\text { dos membros da mesma família, indispensável à própria } \\
\text { subsistência e exercido em condições de mútua dependência e } \\
\text { colaboração, sem a utilização de empregados. }\end{array}$ & $\begin{array}{l}\text { Considera-se profissão habitual ou principal meio de vida a } \\
\text { atividade exercida durante o período compreendido entre o } \\
\text { defeso anterior e o em curso, ou nos } 12 \text { (doze) meses imediata- } \\
\text { mente anteriores ao do defeso em curso, o que for menor. }\end{array}$ \\
\hline $\begin{array}{l}\text { Para se habilitar ao benefício, o pescador deverá apresentar } \\
\text { ao órgão competente do Ministério do Trabalho e Emprego os } \\
\text { seguintes documentos: IV - atestado da Colônia de Pescadores } \\
\text { a que esteja filiado, com jurisdição sobre a área onde atue o } \\
\text { pescador artesanal, que comprove: b) que se dedicou à pesca, } \\
\text { em caráter ininterrupto, durante o período compreendido entre } \\
\text { o defeso anterior e o em curso. }\end{array}$ & $\begin{array}{l}\text { Considera-se ininterrupta a atividade exercida durante o } \\
\text { período compreendido entre o defeso anterior e o em curso, ou } \\
\text { nos } 12 \text { (doze) meses imediatamente anteriores ao do defeso } \\
\text { em curso, o que for menor. }\end{array}$ \\
\hline $\begin{array}{l}\text { Para se habilitar ao benefício, o pescador deverá apresentar } \\
\text { ao órgão competente do Ministério do Trabalho e Emprego os } \\
\text { seguintes documentos: IV - atestado da Colônia de Pescadores } \\
\text { a que esteja filiado, com jurisdição sobre a área onde atue o } \\
\text { pescador artesanal, que comprove: c) que não dispõe de outra } \\
\text { fonte de renda diversa da decorrente da atividade pesqueira. }\end{array}$ & $\begin{array}{l}\text { Somente terá direito ao seguro-desemprego o segurado } \\
\text { especial pescador artesanal que não disponha de outra fonte } \\
\text { de renda diversa da decorrente da atividade pesqueira. }\end{array}$ \\
\hline Inexistente. & $\begin{array}{l}0 \text { pescador profissional artesanal não fará jus, no mesmo ano, } \\
\text { a mais de um benefício de seguro-desemprego decorrente de } \\
\text { defesos relativos a espécies distintas. }\end{array}$ \\
\hline Inexistente. & $\begin{array}{l}\text { A concessão do benefício não será extensível às atividades } \\
\text { de apoio à pesca nem aos familiares do pescador profissional } \\
\text { que não satisfaçam os requisitos e as condições estabelecidos } \\
\text { nesta Lei. }\end{array}$ \\
\hline Inexistente. & O benefício do seguro-desemprego é pessoal e intransferível. \\
\hline Inexistente. & $\begin{array}{l}\text { O período de recebimento do benefício não poderá exceder o } \\
\text { limite máximo variável de que trata o caput do art. 40 da Lei no } \\
7.998 \text {, de } 11 \text { de janeiro de } 1990 \text {, ressalvado o disposto nos } \S \S \\
\text { 4o e } 5 \text { o do referido artigo. }\end{array}$ \\
\hline $\begin{array}{l}\text { Para se habilitar ao benefício, o pescador deverá apresentar } \\
\text { ao órgão competente do Ministério do Trabalho e Emprego os } \\
\text { seguintes documentos: }\end{array}$ & $\begin{array}{l}\text { Cabe ao Instituto Nacional do Seguro Social (INSS) receber e } \\
\text { processar os requerimentos e habilitar os beneficiários, nos } \\
\text { termos do regulamento. }\end{array}$ \\
\hline $\begin{array}{l}\text { Para se habilitar ao benefício, o pescador deverá apresentar } \\
\text { ao órgão competente do Ministério do Trabalho e Emprego os } \\
\text { seguintes documentos: I - registro de pescador profissional } \\
\text { devidamente atualizado, emitido pela Secretaria Especial de } \\
\text { Aquicultura e Pesca da Presidência da República, com antece- } \\
\text { dência mínima de um ano da data do início do defeso }\end{array}$ & $\begin{array}{l}\text { Para se habilitar ao benefício, o pescador deverá apresentar } \\
\text { ao INSS os seguintes documentos: I - registro como pescador } \\
\text { profissional, categoria artesanal, devidamente atualizado no } \\
\text { Registro Geral da Atividade Pesqueira (RGP), emitido pelo } \\
\text { Ministério da Pesca e Aquicultura com antecedência mínima de } \\
1 \text { (um) ano, contado da data de requerimento do benefício. }\end{array}$ \\
\hline
\end{tabular}


(Continuação)

\begin{tabular}{|c|c|}
\hline Como era antes & Como é agora \\
\hline $\begin{array}{l}\text { Para se habilitar ao benefício, o pescador deverá apresentar } \\
\text { ao órgão competente do Ministério do Trabalho e Emprego } \\
\text { os seguintes documentos: II - comprovante de inscrição no } \\
\text { Instituto Nacional do Seguro Social (INSS) como pescador, e do } \\
\text { pagamento da contribuição previdenciária }\end{array}$ & $\begin{array}{l}\text { Para se habilitar ao benefício, o pescador deverá apresentar ao } \\
\text { INSS os seguintes documentos: II - cópia do documento fiscal } \\
\text { de venda do pescado a empresa adquirente, consumidora ou } \\
\text { consignatária da produção, em que conste, além do registro } \\
\text { da operação realizada, o valor da respectiva contribuição } \\
\text { previdenciária de que trata o } § 70 \text { do art. } 30 \text { da Lei no } 8.212 \text {, } \\
\text { de } 24 \text { de julho de } 1991 \text {, ou comprovante de recolhimento da } \\
\text { contribuição previdenciária, caso tenha comercializado sua } \\
\text { produção a pessoa física; }\end{array}$ \\
\hline Inexistente. & $\begin{array}{l}\text { Desde que atendidos os demais requisitos previstos neste } \\
\text { artigo, o benefício de seguro-desemprego será concedido ao } \\
\text { pescador profissional artesanal cuja família seja beneficiária } \\
\text { de programa de transferência de renda com condicionalidades, } \\
\text { e caberá ao órgão ou à entidade da administração pública } \\
\text { federal responsável pela manutenção do programa a suspensão } \\
\text { do pagamento pelo mesmo período da percepção do benefício } \\
\text { de seguro-desemprego. }\end{array}$ \\
\hline
\end{tabular}

QUADRO A.3

Alterações na Lei no 7.998/1990 - Abono salarial

\begin{tabular}{|c|c|}
\hline Como era antes & Como é agora \\
\hline $\begin{array}{l}\text { É assegurado o recebimento de abono salarial no valor de um } \\
\text { salário-mínimo vigente na data do respectivo pagamento, aos } \\
\text { empregados que: }\end{array}$ & $\begin{array}{l}\text { É assegurado o recebimento de abono salarial anual, no valor } \\
\text { máximo de } 1 \text { (um) salário-mínimo vigente na data do respec- } \\
\text { tivo pagamento, aos empregados que: }\end{array}$ \\
\hline Inexistente. & $\begin{array}{l}0 \text { valor do abono salarial anual de que trata o caput será } \\
\text { calculado na proporção de } 1 / 12 \text { (um doze avos) do valor do } \\
\text { salário-mínimo vigente na data do respectivo pagamento, } \\
\text { multiplicado pelo número de meses trabalhados no ano } \\
\text { correspondente. }\end{array}$ \\
\hline
\end{tabular}

Elaboração dos autores, com base na Lei no 13.134/2015. 